\title{
Perspectives on Federal Disclaimer Legislation
}

\author{
John H. Martin†
}

"The law is certainly not so absurd as to force a man to take an estate against his will." So runs the venerable doctrine that an intended recipient of a gift may reject it. ${ }^{2}$ When the refusal-known as either a disclaimer or a renunciation ${ }^{3}$-is made properly, the refusal relates back to the moment of original transfer and the property is treated as passing from the original donor to the substituted taker. ${ }^{4}$

The Tax Reform Act of 1976 raised this property-law principle of rejection and relation back to new prominence. Internal Revenue Code section $2518^{5}$ sets specific conditions under which a refusal will

† Professor of Law, University of North Carolina, Chapel Hill.

1 Townson v. Tickell, 106 Eng. Rep. 575, 576-77 (K.B. 1819) (Abbot, C.J.).

2 The doctrine has long been recognized as to inter-vivos transfers and bequests and devises under a will. Brown v. Routzahn, 63 F.2d 914 (6th Cir.), cert. denied, 290 U.S. 641 (1933); Webster v. Gilman, 29 F. Cas. 547 (C.C.D. Me. 1841) (No. 17,355) (Story, Circuit J.); Schoonover v. Osborne, 193 Iowa 474, 187 N.W. 20 (1922); Chilcoat v. Reid, 154 Md. 378, 140 A. 100 (1928); Stebbins v. Lathrop, 21 Mass. (4 Pick.) 33 (1826); Defreese v. Lake, 109 Mich. 415, 67 N.W. 505 (1896); Seifner v. Weller, 171 S.W.2d 617 (Mo. 1943); Perry v. Hale, 44 N.H. 363 (1862); Albany Hosp. v. Hanson, 214 N.Y. 435, 108 N.E. 812 (1915); Barritt v. Silliman, 13 N.Y. 93 (1855); Perkins v. Isley, 224 N.C. 793, 32 S.E.2d 588 (1945); Roop v. Greenfield, 352 Pa. 232, 42 A.2d 614 (1945); Townson v. Tickell, 106 Eng. Rep. 575, 576-77 (K.B. 1819); Thompson v. Leach, 86 Eng. Rep. 391 (K.B. 1690); Warren v. Rudall, 70 Eng. Rep. 637 (Ch. 1860); Moffett v. Bates, 65 Eng. Rep. 740 (Ch.1857); Andrew v. Trinity Hall, 32 Eng. Rep. 706 (Ch. 1804); T. JARMaN, Wills 565 (8th ed. 1951); J. KeNT, Commentaries *533; 6 W. PAGE, WiIIs $\$ 49.2$ (rev. ed. 1962) [hereinafter cited as PaGe]; Treobald on Wilts II 382 (13th ed. S. Cretney \& G. Dworkin 1971). See also W. Blackstone, Commentaries *201 (where the author states that when a person acquires title in any manner other than by descent, the title vests by his own act or agreement). Under Roman Law, heres, the name for those who take title by intestacy or under a will, could refuse title. See generally W. Buckiand, Roman Law 304-07 (3d ed. 1963); M. Radin, HaNdBook of Roman Law 399, 410, 422, 459-60 (1927).

3 The two words have the same meaning. The term "disclaimer" will be used in this article because it is the term used in the Internal Revenue Code, I.R.C. $\$ 2518$, and in recent uniform acts, Uniform Disclatmer of Property InTerests Act, Uniform Disclaimer of Transfer by Wills, Intestacy or Appointment Act, and Uniform Disclaimer of Transfer UNDER NONTESTAMENTARY INSTRUMENTS ACT, all approved in 1973 by the National Conference of Commissioners on Uniform State Laws.

4 See, e.g., Schoonover v. Osborne, 193 Iowa 474, 187 N.W. 20 (1922); Seifner v. Weller, 171 S.W.2d 617 (Mo. 1943); Albany Hosp. v. Hanson, 214 N.Y. 435, 108 N.E. 812 (1915); Barritt v. Silliman, 13 N.Y. 93 (1855); Perkins v. Isley, 224 N.C. 793, 32 S.E.2d 588 (1945). See also 3 American LaW of Property $\$ 14.15$ (A.J. Casner ed. 1952).

Section 2518 provides:

SEC. 2518. DISCLAIMERS

(a) Gengral Rute. For purposes of this subtitle, if a person makes a qualified disclaimer with respect to any interest in property, this subtitle shall apply with respect 
be given effect for tax purposes, so that the disclaimant will be viewed as not having received the property and thus will not be treated as the transferor when the interest passes to the eventual taker. To provide consistency, section 2045 adopts the rules of section 2518 for federal estate tax purposes, and section 2614(c) does the same for the tax on generation-skipping transfers. ${ }^{6}$

The primary purpose of the 1976 legislation was to bring uniformity to the treatment of disclaimers under federal tax law in the face of widely varying requirements for a proper refusal under state law. This article contends that the 1976 reforms failed to achieve this goal, while introducing considerable additional complexity to the field of estate planning. Because this failure is apparently the result of limitations inherent in the current statute, the article considers existing alternatives for preserving favorable tax treatment

to such interest as if the interest had never been transferred to such person.

(b) Qualified Disclaimer Defined. For purposes of subsection (a), the term "qualified disclaimer" means an irrevocable and unqualified refusal by a person to accept an interest in property but only if-

(1) such refusal is in writing,

(2) such writing is received by the transferor of the interest, his legal representative, or the holder of the legal title to the property to which the interest relates not later than the date which is 9 months after the later of-

(A) the day on which the transfer creating the interest in such person is made, or

(B) the day on which such person attains age 21 ,

(3) such person has not accepted the interest or any of its benefits, and

(4) as a result of such refusal, the interest passes without any direction on the part of the person making the disclaimer either-

(A) to the spouse of the decedent, or

(B) to a person other than the person making the disclaimer.

(c) OTHER RuLes. For purposes of subsection (a)-

(1) DisCLAIMER OF UNDIVIDED PORTION OF INTEREST. A disclaimer with respect to an undivided portion of an interest which meets the requirements of the preceding sentence shall be treated as a qualified disclaimer of such portion of the interest.

(2) Powers. A power with respect to property shall be treated as an interest in such property.

This section was originally enacted as part of The Tax Reform Act of 1976, $\S 2009(b)(1)$, Pub. L. No. 94-455, 90 Stat. 1893. Section 2518(b)(4) was amended to read as indicated by section 702(m)(1) of the Revenue Act of 1978, Pub. L. No. 95-600, 92 Stat. 2763. Before it was amended, section $2518(b)(4)$ read: "[a]s a result of such refusal, the interest passes to a person other than the person making the disclaimer (without any direction on the part of the person making the disclaimer)."

' I.R.C. $\$ \S 2045,2614$ (c). A disclaimer has estate tax consequences when the operation of disclaimer rules generates a marital or charitable deduction or results in the denial of such a deduction. For example, if the beneficiary of a specific bequest under a will disclaims his interest pursuant to the requirements of section 2518 , and the disclaimed property passes as a result to a charity or the decedent's surviving spouse, a charitable deduction under section 2055 or marital deduction under section 2056 would be created or increased. Conversely, if a surviving spouse or a charity should disclaim property, the marital or charitable deduction might be decreased or eliminated. 
for disclaimers. It concludes that these alternatives are unsatisfactory and that fairness and simplification, in addition to the fundamental purpose of transfer taxation, indicate that disclaimers themselves should be subject to taxation.

\section{The Unsuccessful Search for Uniformity and Certainty}

A. Policy, Uncertainties, and a Federal Solution

1. Common Law of Disclaimers. The underlying policy given effect in the property-law doctrine of disclaimer is that a person should not be saddled with a burdensome estate or interest against his will. ${ }^{7}$ Although a gratuitous transfer is commonly beneficial, whether it is a benefit or detriment is for the donee to decide. ${ }^{8}$ Thus, "the law is not so absurd as to force" an acceptance of property because the law recognizes the importance of freedom of choice as well as the need for the ability to escape unwanted burdens. The radical young student is as able to reject arbitrarily a large, unrestricted inheritance from his wealthy parent as is another person to refuse to take Blackacre because the gift requires the donee to provide lifetime support to the donor's favorite nephew.

This freedom to choose and to refuse has long been recognized for transfers by deed or will..$^{\ominus}$ But historically the common-law theory governing passage of property by intestate succession overrode the policy undergirding disclaimers. Because of the predominant importance of knowing the new owner of the property from the instant of the prior holder's death, ${ }^{10}$ the common-law doctrine of "descent cast" placed title in the heir without regard to the recipi-

7 See Chilcoat v. Reid, 154 Md. 378, 140 A. 100 (1928); Seifner v. Weller, 171 S.W. 2d 617 (Mo. 1943); Barritt v. Silliman, 13 N.Y. 93 (1855); Warren v. Rudall, 70 Eng. Rep. 637 (Ch. 1860). See also Howe, Renunciation by the Heir, Devisee or Legatee, 42 KY. L.J. 605, 606.09 (1954).

${ }^{8}$ Chilcoat v. Reid, 154 Md. 378, 140 A. 100 (1928); Seifner v. Weller, 171 S.W. 2d 617 (Mo. 1943); Townson v. Tickell, 106 Eng. Rep. 575 (K.B. 1819). A legatee or devisee may refuse even a beneficial gift. Schoonover v. Osborne, 193 Iowa 474, 187 N.W.20 (1922); Perkins v. Isley, 224 N.C. 793, 32 S.E.2d 588 (1945). Beneficiaries are presumed to accept a beneficial gift, however, absent a clear and unequivocal renunciation. See Webster v. Gilman, 29 F. Cas. 547 (C.C.D. Me. 1841) (No. 17,355) (Story, Circuit J.); Schoonover v. Osborne, 193 Iowa 474 , 187 N.W.20 (1922); Chilcoat v. Reid, 154 Md. 378, 140 A. 100 (1928); Defreese v. Lake, 109 Mich. 415, 67 N.W. 505 (1862); Albany Hosp. v. Hanson, 214 N.Y. 435, 108 N.E. 812 (1915); Perkins v. Isley, 224 N.C. 793, 32 S.E.2d 588 (1945); Roop v. Greenfield, 352 Pa. 232, 42 A.2d 614 (1945).

- See authorities cited in note 2 supra.

$101 \mathrm{E}$. Coke, The First Part of the Institutes of the Laws of England $\S 145$, at 102.a (18th ed. F. Hargrave \& C. Butler, London 1823) (1st ed. London 1628); G. GILBERT, LAW OF Tenures $39 \& \mathrm{n}$. 
ent's desires. ${ }^{11}$ The application of the doctrine of descent cast continued long after its usefulness ended; even today, some jurisdictions provide a separate rule for intestacy, refusing to permit disclaimer of property passing in that fashion. ${ }^{12}$

Several consequences flow from a state's decision to allow or not to allow a disclaimer in any particular case. An effective disclaimer causes the property to be transferred to another person as if directed to that destination by the original donor. ${ }^{13}$ The disclaimant is treated as never having been involved. This "relation-back" approach in turn triggers several consequences beneficial to the disclaimant. Generally, the creditors of the disclaimant cannot reach

" For an excellent discussion of the ancient distinction between property passing by intestate succession and by will or devise, see Lauritzen, Only God Can Make an Heir, 48 Nw. U.L. Rev. 568 (1953).

12 Inability of an heir to disclaim his intestate share is indeed the general rule absent a change by statute or case law. 3 AMERICAN LAw of ProperTy $\$ 14.15$ (A.J. Casner ed. 1952). Several authorities have argued, however, that there is no logical reason to deny the right to refuse to those who take by descent while allowing those who take by will or devise to do so, see Model Probate Code \& 58, comment (1946); Uniform Probate Code \& 2-801, comment (1975); and PAGE, supra note $2, \S 49.1$, and the rule has been changed by statute in the great majority of states. The following state statutes authorize disclaimer of an intestate share: Alaska Stat. \$ 13.11.295(a) (1972 \& Cum. Supp. 1977); ARIz. Rev. Stat. \& 14-2801(A)(1) (1975 \& Supp. 1978-79); ARK. Stat. ANn. $\$$ 62-3201(a), 62-3202 (Supp. 1977); Cal. Prob. Code $\S \S 190,190.1$ (West Supp. 1978); Colo. Rev. Stat. $§ 15-11-801(1)$ (1973); ConN. Gen. Stat. AnN. $\S 45-300$ (West Supp. 1978); Dec. Code tit. 12, § 512(a) (Cum. Supp. 1977); Fra. Stat. ANN. $\$ 732-801$ (2)(a)(1) (West Supp. 1978); Ga. Code $§ 113-824(a)$ (1975); Haw. Rev. Stat. 560:2-801(a) (1976); Idaho Code \$ 15-2-801(a)(1) (Cum. Supp. 1978); In.. AnN. Stat. ch. 3, § 2-7(a) (Smith-Hurd Cum. Supp. 1978); IND. Code ANN. § 29-1-6-4 (Burns 1972 \& Cum. Supp. 1978); Iowa Code Ann. \$ 633.704(1) (Cum. Supp. 1978-1979); Kan. Stat. § 592291 (1976); Ky. Rev. Stat. Ann. $\$ 394.610$ (Baldwin Cum. Supp. 1976); La. Crv. Code AnN. art. 977 (West 1952); ME. Rev. Stat. tit. 18, 1272 (Cum. Supp. 1978-1979); MD. Est. \& Trusts Code Ann. $\$$ 9-201(a) (Cum. Supp. 1978); Mass Gen. Laws Ann. ch. 191A, § 2(1) (West Cum. Supp. 1978-1979); Mich. Comp. LAws ANN. $\$ 554.501$ (Cum. Supp. 1978-1979); Minn. Stat. AnN. $\S \S 525.532(1)(a), 525.532(2)$ (West 1975 \& Supp. 1978); Mo. Rev. Stat. $\S$ 474.490 (1956); Mont. Rev. Codrs Ann. \$91A-2-801 (Supp. 1977); Neb. REv. Stat. § 30-2352 (a)(1)(1975); N.M. Stat. ANN. $\$ \$ 32 A-2-801$ (Supp. 1975); N.Y. Est., Powers \& Trusts Law $\S \S 2-1.11$ (a)(1), 2-1.11(b) (McKinney Cum. Supp. 1977-1978); N.C. GEN. STAT. §§ 29-10, 31B1(a)(1976); N.D. CENT. Code $\$ 30.1-10-01$ (1) (1976 \& Supp. 1977); Ohro Rev. Code ANN. $\S$ 2105.06.1 (Page 1976); OKLA. Stat. ANN. tit. 84; §§ 22(1), 23 (West Cum. Supp. 1978-1979); Or. Rev. Stat. $\$ 112.652$ (1973); 20 PA. Cons. Stat. Ann. $\$ \S 6103(a), 6201$ (Purdon 1975 \& Cum. Supp. 1978-1979); R.I. GEN. LAwS \$\$ 34-5-1, 34-5-2 (1969); S.D. CompILED LAws ANN. $\$$ 43-4-29 (Supp. 1978); Tenn. Code Ann. \$ 31-103(a) (Cum. Supp. 1978); Tex. ProB. Code ANN. $\$ 37(A)$ (Vernon Cum. Supp. 1978); UTAH Code ANN. \& 75-2-801(1) (Supp. 1977 Uniform Probate Code); VA. CoDE $\$ 64.1-188$ (1973); WASH. REv. CoDE ANN. §§ 11.86.010(1), 11.86.020 (Supp. 1978); W. VA. CodE $\$ 42-4-3$ (1966 \& Cum. Supp. 1978); Wis. Stat. AnN. $\$ 852.13$ (West 1971 \& Cum. Supp. 1978-1979).

Many of these statutes are based on UnIform Probate Code § 2-801 (1975), UNIFORM Disclaimer of Property INTERests Act \& 1, or Uniform Disclaimer of Transfers by WiLl, INTESTACY OR APPOLNTMENT ACT $\$ 1$, all of which authorize disclaimer of an intestate share.

'B See note 4 supra. 
the property, for the debtor never has any interest in it. ${ }^{14}$ If the transfer is by death, an inheritance tax usually cannot be assessed on the receipt by the disclaimant, for such receipt never occurs. ${ }^{15}$ Similarly, if the jurisdiction has a gift tax, a relation-back theory would deny the existence of a taxable transfer, for the disclaimant never acquires an interest that could form the subject of a subsequent gift. ${ }^{16}$

Significantly, as these consequences became predictable and certain, they provided reasons for rejecting gifts beyond a desire simply to escape from unwanted burdens or to exercise independence. Creditors could be avoided, or at least be kept from reaching a ready fund; taxes could be deflected or minimized; and the testamentary scheme of the testator could be revised to comply with either wishes not found in a valid will or the family's notion of what was the intended pattern of distribution. In recent years, these new motives seem to have completely overshadowed the original justifications for disclaimers. ${ }^{17}$

2. Pre-1976 Federal Tax Treatment. Until 1976 the treatment of disclaimers for federal tax purposes fairly consistently followed the property-law pattern just sketched. In particular, except for a brief time with regard to qualification for the marital deduction, the

1" See, e.g., Hoecker v. United Bank, 476 F.2d 838 (10th Cir. 1973); Schoonover v. Osborne, 193 Iowa 474, 187 N.W. 20 (1922), 3 AMERICAN LAW of Property $§ 14.15$ (A.J. Casner ed. 1952). Some states do not permit the rights of creditors to be blunted by the theory of relation back when the transferee seeks exclusively to undermine those rights, e.g., Estate of Reed, 566 P.2d 587 (Wyo. 1977); In re Kalt's Estate, 16 Cal. 2d 807, 108 P.2d 401 (1940). There is some question whether the holding in Kalt remains valid, however, in light of a more recent California statute, CAL. ProB. Code $\$ 190.6$ (West Supp. 1978), that expressly endorses the relation-back theory when property is disclaimed. See Beck, How to Look a Gift Horse in the Mouth-Disclaimers Under California Law and the Tax Reform Act of 1976, 18 SANTa CLARA L. REv. 217, 231-32 (1978).

${ }^{15}$ See, e.g., People v. Flanagin, 331 Ill. 203, 162 N.E. 848 (1928); In re Stone's Estate, 132 Iowa 136, 109 N.W. 455 (1906); Bouse v. Hull, 168 Md. 1, 176 A. 645 (1935). This principle too was not universal: the Connecticut statute provides that relation back will not apply for inheritance tax purposes, Conn. Gen. Stat. ANN. $\$ 45-312$ (West Cum. Supp. 1978). California and Indiana formerly had statutes to the same effect. 1945 Cal. Stats. c.1014, $\$ 2$ (current version at CAL. REv. \& TAX CoDE $\S 13409$ (West Cum. Supp. 1978)); 1953 Ind. Acts c. 112, $\S$ 604 (current version at IND. Code ANN. \& 29-1-6-4 (Burns Cum. Supp. 1978)).

" Brown v. Routzahn, 63 F.2d 914 (6th Cir.), cert. denied, 290 U.S. 641 (1933).

17 "Once in a while there are non-tax considerations for disclaiming, but most often a disclaimer will be executed for the purpose of saving . . . taxes . . . " Roche, General Comments and Implications of TRA 1976, PROB. NoTEs, Spring 1978, at 20. Minimization of taxes and avoidance of creditors are the two most common motives. Newman \& Kalter, Disclaimers of Future Interests: Continuing Problems and Suggested Solutions, 49 Norre DAME LAw. 827, 829 (1974); Black, The Effect of Renunciations and Compromises on Death and Gift Taxes, 3 VAND. L. REv. 241, 242 (1950). 
pre-1976 federal tax law applied the doctrine of relation back. ${ }^{18}$ But the development of federal law regarding disclaimers has been not only parallel to, but also dependent on, local law: favorable application of the federal tax rules was, before 1976, allowed only when the disclaimer was valid under state law. ${ }^{19}$ Because the states have prescribed different procedures for effecting a disclaimer, ${ }^{20}$ have varied in important respects with respect to the types of interests that may be disclaimed, ${ }^{21}$ and have differed across a wide spectrum in prescribing time limits for making the disclaimer, ${ }^{22}$ there has existed a very real and unsettling lack of uniformity. ${ }^{23}$

Is In the federal tax context, the relation-back principle may mean that, for example, a disclaimant cannot be a donor for gift-tax purposes and is not the transferee for purposes of applying the rules regarding marital and charitable deductions. For decedents dying before October 4, 1966, a disclaimer by a legatee or devisee that caused the property to go to the surviving spouse was treated, for purposes of the marital deduction, as passing from the decedent to the disclaimant. Thus no marital deduction was allowed for the disclaimed property. I.R.C. $₹ 2056$ (d)(2) (as amended by Act of Oct. 4, 1966, Pub. L. No. 89-621, § 1(a), 80 Stat. 872). For decedents dying on or after October 4, 1966, the disclaimed property was treated as passing from the decedent to the surviving spouse. I.R.C. $\$ 2056(\mathrm{~d})$ (2) (repealed 1976). The relation-back effect of a disclaimer was thus recognized, and a marital deduction could be generated by another person's disclaimer.

Before 1976, such disclaimer rules were found in many different locations in the Code, but the results they produced with regard to the relation-back principle were relatively uniform. See I.R.C. $\$$ 2514(b) (as amended by Tax Reform Act of 1976, Pub. L. No. 94-455, $\$ 2009$ (b)(4)(F), 90 Stat. 1894) and Treas. Reg. $\$ 25.2514-3(\mathrm{c})(5)$ (1958) (pertaining to powers of appointment/gift tax treatment); I.R.C. \$ 2041(a) (as amended by Tax Reform Act of 1976, Pub. L. No. 94-455, § 2009(b)(4)(A), 90 Stat. 1894) and Treas. Reg. $\S 20.2041-3($ d)(6) (1942) (powers of appointment-estate tax treatment): I.R.C. \$ 2055(a) (amended by Pub. L. No. 94-455, 2009(b)(4)(B), 90 Stat. 1894 and Treas. Reg. $\$ 20.2055-2$ (c) (1958) (charitable deduction); I.R.C. $\$ 2056$ (d) (repealed 1976) and Treas. Reg. $\$ 20.2056$ (d) (1958) (marital deduction); and Treas. Reg. $\$ 25.2511-1$ (c) (1958) (gifts in general). The cited regulations are still in effect, as new regulations under Pub. L. No. $94-455$ have not yet been promulgated. In addition, new section 2518 retains relation-back treatment for qualified disclaimers of gifts, treatment that section 2045 carries over into the estate tax sections of the Code.

10 Treas. Reg. §§ 25.2514-3(c)(5) (1958); 25.2511-1(c)(1958); 20.2041-3(d)(6)(1942).

20 See, e.g., GA. CoDE ANN. \$ 113-824(a) \& (b) (1975) (file writing with county court where proceedings in decedent's estate have been or could be commenced); N.Y. EsT. PowERS \& Trusts LAW \& 2-1.11 (McKinney Cum. Supp. 1977-1978) (file writing and affidavit stating no consideration received; service on administrator of estate).

${ }^{21}$ E.g., Mo. Ann. Stat. $\$ 474-490$ (Vernon 1956) (heir or devisee); Wash. REv. Code AnN. $\S 11.86 .010$ (1) (Supp. 1978) (broad types of interests specified, including donee of powers of appointment and those who take by right of survivorship).

2 See, e.g., Oho Rev. Code Ann. $\$ 2105.061$ (Page 1976) (60 days); N.Y. Est., Powers \& Trusts Law § 2-1.11(b) (McKinney Cum. Supp. 1977-1978) (one year); Mo. AnN. Stat. \& 474.490 (Vernon 1956) (no time limit specified).

23 The unsettled situation precipitated several proposals for state legislation to clarify when and how disclaimers could be made. See the authorities cited in notes 153-154 infra. Suggestions for federal tax legislation on disclaimers were also made. See the authorities cited in notes $156-157$ infra. 
Two cases illustrate some of the disparities that existed before 1976 in the administration of disclaimers under federal tax law. In Hardenbergh $v$. Commissioner, ${ }^{24}$ taxpayers renounced their interests in an intestate estate in order to fulfill the decedent's wishes contained in an unexecuted will. The court found, however, that the action of taxpayers constituted a gift and thus sustained the assessment of federal gift tax. It emphasized that under local law takers by intestacy had no power to prevent the immediate vesting of the property and held that this rule of state law meant taxpayers had to pay the federal tax, even though beneficiaries of testate estates would not have had to do so. In Keinath $v$. Commissioner, ${ }^{25}$ the disclaimer was made by decedent's son, who was the holder of a remainder interest contingent upon surviving the life tenant, his mother. He elected to refuse the gift within two months after the life tenant's death, some 19 years after the remainder was created. Despite the delay, the court gave the disclaimer effect for tax purposes, deciding that it was permissible under local law (and reasonable under the federal standard) for the recipient to wait until the interest was indefeasibly vested before deciding whether to disclaim. ${ }^{28}$

Dissatisfaction with the variations in tax consequences produced by the differences in underlying state law was the fundamental reason for the revisions in the 1976 Tax Reform Act. As stated by the Joint Committee on Taxation: "The Congress believed that definitive rules concerning disclaimers should be provided for estate and gift tax purposes to achieve uniform treatment. In addition, the Congress believed that a uniform standard should be provided for determining the time within which a disclaimer must be made." 27 This language suggests that Congress intended to set aside the inconsistent tax results caused by ancient state law distinctions such as those prohibiting disclaimer of an interest acquired via intestate succession. ${ }^{28}$ It also indicates that Congress sought to eliminate tax benefits arising out of long delayed decisions given effect under local property law solely because indefeasible vesting of the interest has

${ }^{24} 198$ F.2d 63 (8th Cir.), cert. denied, 344 U.S. 836 (1952).

25480 F.2d 57 (8th Cir. 1973).

23 It is interesting to note that the court found the motivation for the refusal-tax minimization-irrelevant. $I d$. at 66 .

27 Joint Comm. on Internal Revenue Taxation 94TH Cong., 2D Sess., General ExplanaTION OF THE TAX REFORM ACT OF 1976, at 590 (1976) [hereinafter cited as GENERAL Explanation].

${ }^{23}$ Id. at $590-91$. 
not occurred earlier. ${ }^{29}$ Enactment of section 2518 thus represents a quest for the holy grail of uniformity. To some commentators, the crusade has appeared successful..$^{30}$ To others, including this writer, the effort fell markedly short of the objective. ${ }^{31}$

\section{B. Continued Bifurcation}

1. Statutory Difficulties: "The Interest Passes." In pulling together the scattered code references to disclaimers ${ }^{32}$ and attempting to prescribe a uniform and predictable outcome of refusals to accept gratuitous transfers, Congress imposed four conditions that must be satisfied for the disclaimer to be qualified for federal tax purposes. ${ }^{33}$ The most important of these new disclaimer rules is the requirement of section $2518(\mathrm{~b})(4)$ that, following the disclaimer, the interest pass to a person other than the disclaimant without any direction by the disclaimant. Since the section itself does not contain any transfer mechanism, this passing to another must be triggered elsewhere. Yet, the logical means of effecting this transferstate law-will of course not cause a shift of the interest unless the disclaimer itself is also effective under local law, even if the purported act of disclaimer otherwise satisfies section 2518.

This dependency on local property law presents two problems. First, if state law is not the same as federal law (as indeed it usually is not), ${ }^{34}$ broad areas of potential conflict exist, producing situations

2 See id. at 590-91. Keinath, 480 F.2d 57 (8th Cir. 1973), was cited as indicative of the problem of timing under prior law. Both the House Report, House CoMm. ON WAYS AND Means, Estate and Gift Tax Reform Act of 1976, H.R. Rep. No. 1380, 94th Cong., 2d Sess. 66, reprinted in [1976] U.S. CoDE CoNG. \& AD. NEws 3356, 3420 [hereinafter cited as House REPORT], and the GENERAL EXPLANATION, supra note 27, at 590, specifically cited Keinath in a negative comment on the difficulty of ascertaining the meaning of the pre-1976 law's "reasonable time" requirement. To resolve the problem, Congress substituted a maximum time for disclaimer of nine months, running from the moment of a taxable transfer. For discussion of some problems this timing rule creates, see text and notes at notes 61-69 infra.

30 Borod, Lawson \& Smith, Marital Deduction Planning Under the Tax Reform Act of 1976, 7 MEM. ST. U.L. REv. 181, 184 (1977); Zartisky, The Estate and Gift Tax Revisions of the Tax Reform Act of 1976, 34 WASH. \& LEE L. Rev. 353, 401, 404 (1977); cf. Note, The 1976 Estate and Gift Tax Reform: A Trip Through the Maze, 46 U. CINN. L. REv. 471, 498 (1977) ("To provide uniformity, the Act has adopted a federal disclaimer rule").

31 See, e.g., J. McCord, 1976 Estate AND GifT Tax Rerorm \$§ 5.26-.32 (1977); Glasser, Disclaiming an Interest in Property Under New Rules: Does $\$ 2518$ Do the Job? , 4 Est. PLAN. 204, 407 (1977); Moore, TRA-Disclaimers, Contemplation of Death and Anti-Byrum Rule, 11 U. Miami Inst. Est. Plan. 4-1 to 4-25 (Workshop Papers 1977).

32 See note 18 supra.

23 I.R.C. $\$ 2518($ b).

अ For the broad variations between state and federal provisions and among state laws, see text and notes at notes 20-23 supra. See also Schwartz, Effective Use of Disclaimers: Frustrating the Planner and Federal Tax Policy, 19 B.C.L. Rev. 228 (1978): To note but two examples of the difficulty: the federal requirement in section $2518(\mathrm{~b})(4)(\mathrm{A}) \&(\mathrm{~B})$ that the 
in which a refusal satisfies one but not both laws. Second, inasmuch as state laws themselves vary, the extent of this clash between local and federal approaches will vary from jurisdiction to jurisdiction. In short, despite the avowed intent and policy of Congress, the enactment of section 2518 seems not to have achieved uniformity in the tax treatment of disclaimers.

A closer look at these conflicts discloses the seriousness of the matter. Assume initially that the conditions of section 2518 are met, but that state law does not recognize the disclaimer under the particular circumstances. This failure to qualify under state law might stem from any one of several factors, such as filing the disclaimer with the wrong official, ${ }^{35}$ too great a delay before acting, ${ }^{36}$ or an improper attempt to disclaim only in part. ${ }^{37}$ But, just to sharpen the

disclaimer be delivered to one of several recipients is not particularly burdensome, but because the permissible recipients may be different from those listed in state statutes, the uncautious may be trapped by the lack of parallelism. Similarly, although, as a general proposition, the nine-month time period is a reasonable condition, it too carries potential for conflict with differing state statutory provisions. See note 22 supra.

ss Section 2518(b)(2) designates the transferor, his legal representative, or the holder of legal title to the property as proper recipients of the disclaimer. Filing with these parties would be insufficient, for example, in states that have adopted the Uniform Disclaimer of Transfers by Will, Intestacy or Appointment Act which appears also in section 2-801 of the Uniform Probate Code. Section 2 of that Act (section 2-801(b)(3) of the Uniform Probate Code) requires the disclaimer to be filed with the court having jurisdiction over administration of the estate.

${ }^{36}$ Many states set a time period shorter than the nine months provided under federal law. The several Uniform Acts concerning disclaimers, see note 154 infra, specify a limit of six months, although the Uniform Probate Code, like section 2518, uses nine months. At least one state has a time period as short as 60 days. OHro Rev. Code AnN. $§ 2105.06 .1$ (Page 1976).

${ }^{37}$ The common law permitted a partial disclaimer in only a few narrow situations. In the case of a single gift, the recipient could not accept the beneficial portion while rejecting the burdensome part. When several gifts were made to the same recipient, however, he could accept some and reject others if they were truly separable. See 3 AMERICAN LAW OF PROPERTY $\$ 14.15$ (A.J. Casner ed. 1952); O'Connell, Federal Tax Aspects of Disclaimers in Massachusetts, 54 B.U.L. REv. 1, 12 (1974).

With the exception of Louisiana, Missouri, Ohio and Rhode Island, whose statutes are silent on the question, all states that have statutes on disclaimers, see note 12 supra, explicitly permit partial disclaimer. Most of these enabling statutes do not explain what is meant by a partial disclaimer, although in general a statute authorizing partial disclaimers would seem to allow the recipient to divide a single gift, accepting only the parts he wants. Some statutes are very specific, however. The Arkansas statute, for example, defines the "interest" that may be rejected as "the whole of any property . . . or any fractional part thereof, share or particular portion or . . . power to appoint, consume, apply or expend property, or any other right, power, privilege or immunity." ARK. STAT. AnN. \$ 62.3201(b) (Supp. 1977). Similar broad language is found in CaL. Prob. Code $\$ 190(\mathrm{~b})$ (West Supp. 1978); Mass. Gen. Laws AnN. ch. 191A $\S 1$ (West Cum. Supp. 1978-79); Minn. Stat. Ans. § 525.532 (1)(b) (West 1975); Okza. Stat. AnN. tit. 84, \&2 (West Cum. Supp. 1978-79). On the other hand, several states do place limits upon the use of partial disclaimers. New York, for example provides that a fractional or specific dollar disclaimer is permissible, but that a renunciation limited to certain specified terms is ineffective. N.Y. Est., PowErs \& Trusts Law § 2-1.11(e) (McKin- 
illustration, the jurisdiction could be one that does not permit disclaimer of an intestate share. In other words, the statute's reliance on local law applies even under the facts of Hardenbergh $v$. Commissioner, ${ }^{38}$ the very situation Congress sought to account for in section $2518 .^{39}$

Clearly Congress intended to recognize under the tax law those refusals of property that satisfy the federal test regardless of their characterization at the local level. But because the act of refusal itself cannot redirect the interest unless that act is recognized by local property law, the statute's requirement that the interest pass simply cannot be met without the conditions of the state's disclaimer law being satisfied. ${ }^{40}$ Ultimately, the federal law requires

ney Cum. Supp. 1977-78). Some statutes provide that a disclaimer of a present, passessory interest operates also as a refusal of a future interest in the same property. See Iowa CoDE Ann. $\S 633.704$ (West Cum. Supp. 1978-79); Mich. Comp. Laws ANn. $§ 554.503$ (Cum. Supp. 1978-79); N.Y. Est., Powers \& Trusts Law \& 2-1.11(d) (McKinney Cum. Supp. 1977-78); VA. CODE $64.1-190$ (1973). Texas, meanwhile, permits partial disclaimers, but provides a limitation that is consonant with the general approach when no statute exists: "[A] partial disclaimer of property which is subject to a burdensome interest created by the decedent's will shall not be effective unless such property constitutes a gift which is separate and distinct from undisclaimed gifts." Tex. Prob. Code ANn. § 37A(e) (Vernon Cum. Supp. 1978).

Although the extent to which section 2518 permits partial disclaimers is not clear, see text and notes at notes 76.84 infra, it is clear that a person can renounce in part and satisfy the federal standards while failing to meet state restrictions on partial disclaimers. The reverse situation in which state conditions are satisfied but federal requirements are not, has been openly acknowledged as a possibility by the commentary to at least one state's law. MD. Est. \& Trusts Code ANN. \& 9-201, comment (Cum. Supp. 1978).

${ }^{38} 198$ F.2d 63 (8th Cir.) cert. denied, 344 U.S. 836 (1952).

31 One important statement in the legislative history seems to refer to the Hardenbergh fact situation:

If the requirements of the provision are satisfied, a refusal to accept property is to be given effect for Federal estate and gift tax purposes even if the applicable local law does not technically characterize the refusal as a 'disclaimer' or if the person refusing the property was considered to have been the owner of the legal title to the property before refusing acceptance of the property.

General Explanation, supra note 27, at 590-91. For a fuller discussion of this statement and the intent of Congress here, see text and notes at notes 48-53 infra.

- The facts in Hardenbergh suggest a way to comply with the "passing" requirement of I.R.C. section 2518(b)(4) even without a disclaimer valid under state law. After renouncing their interests, the taxpayers in Hardenbergh petitioned for a court order directing the disposition of the rejected interests. The Minnesota Probate Court complied and entered an order purporting to distribute the property. It might be argued that the property passed to another without direction from the disclaimants, thus meeting the test of I.R.C. section 2518(b)(4). It seems questionable, however, whether other courts in jurisdictions that do not recognize the renunciation of an intestate share would be so cooperative in designating the next taker and ordering the transfer. Moreover, the Eighth Circuit regarded the court order as only an agency that the putative disclaimants used to effect delivery of interests they actually transferred. Either way, if courts will not designate the next taker or if entering a court order is viewed as a transfer by disclaimant, it appears that dual requirements continue despite the legislative intent that there be but one. 
compliance with state disclaimer rules if a disclaimer is to obtain favorable tax treatment. ${ }^{41}$ In most cases, a system of dual requirements will continue to apply. ${ }^{42}$

2. Alternative Approaches to the Statutory Language. One reaction to the disquieting possibility that dual requirements continue to operate is to shift the focus of inquiry from the statutory language to the legislative history. Since it suggests Congress intended a unitary approach, this history might well be construed as indicating that characterization and effect under state property law are irrelevant; if the refusal complies with section 2518 , the rejection is effective for tax purposes..$^{43}$ Certainly federal tax law can depart from state property law, so that a particular transaction is treated differently for tax purposes than under local property law. ${ }^{44}$ If accurate, however, this interpretation of the statute would permit

Curiously, in its description of the negative aspects of pre-1976 law, the House Ways and Means Committee stated: "The Federal tax consequences of a disclaimer will also depend upon the effectiveness of the disclaimer in passing property to someone else." House REPORT, supra note 29, at 66 . This statement, as a criticism of prior law, was omitted from the General Explanation, supra note 27, although that document otherwise follows the House Report almost verbatim with regard to disclaimers.

11 In effect Congress seems to have been far more successful in the converse of the Hardenbergh situation, i.e., when the disclaimer meets the requirements of state property law but fails to qualify under federal standards. The facts of Keinath v. Commissioner, 480 F.2d 57 (8th Cir. 1973), present one such situation. Other cases of such inconsistency might arise, as before, from any one of a number of factors such as differences in the persons qualified to receive the notice of disclaimer or differing rules on partial disclaimers. This problem concerned Congress as much as the other. See note 29 supra. By setting minimum standards, Congress seems to have uniformly denied federal tax benefits for such ineffective refusals no matter what transpires in property-law terms. Yet surprisingly, one recent commentary on the new disclaimer rules has suggested that section 2518 should not be treated as the exclusive method for obtaining tax recognition of a disclaimer. Stephens \& Calfee, Skip to M'Loo, 32 TAX L. REv. 443, 608-09 (1977). Rather, it intimates that the new rules only supply one certain path to achieve favorable treatment, leaving other routes open. Thus, a disclaimer, effective in the local jurisdiction and consonant with the spirit, although not all the conditions of the federal statute, might still be recognized for tax law purposes. This suggestion-which is made with particular regard to situations in which the recipient is unaware of the interest until after the nine-month federal disclaimer period has elapsed-is dubious in light of the clear policy in favor of unifying the law of disclaimer. It conflicts with the legislative history and countenances an uncertain and diffuse approach to disclaimers and their consequences.

12 Of course, in some cases the federal and state conditions may dovetail, providing a single system of requirements.

${ }^{43}$ The legislative history, the most pertinent part of which is quoted in note 39 supra, gives strong support to this argument. See House REPORT, supra note 29, at 65-68; GENERAL Explanation, supra note 27, at 589-92.

w This expedient of simply ignoring the state property-law label for federal tax purposes is, of course, familiar in estate tax law. For example, when a married man dies, his gross estate includes the full value of his wife's dower interest or elective share. I.R.C. $\$ 2034$. In a similar vein, an asset held jointly with survivorship rights may be wholly included in the gross estate of the first joint tenant to die even though the surviving tenant under local property law owns 
the disclaimant to keep the property he has rejected for tax purposes; under property law it goes nowhere else. If the language of section 2518(b)(4), that the interest must pass to another, means anything, it means the disclaimant cannot keep the property. Consequently, it seems highly unlikely that Congress would have adopted this particular departure of tax law from property law..$^{45}$

Stretching the interpretative possibilities, could it be that the new disclaimer rules were intended to override state law-even for property purposes? Given some of the broad statements in the legislative history, ${ }^{48}$ a few legislators may indeed have believed this was the purpose of the 1976 reform. Setting to one side, for later exploration, the question whether Congress could do just that, ${ }^{47}$ the central objection to this interpretation derives from the same source as the original problem: the lack of any transfer mechanism in the statute. The Code is barren of any direction for disposition of the property.

A third alternative, between these two extremes, is to read the statute as applying to a disclaimant who meets the requirements of section 2518 and who somehow causes the interest to pass immediately, whether or not he does so by a disclaimer conforming to state law. Thus, the recipient of property might, while meeting federal standards, simply give any interest in the property he does not want to another taker. The chief objection to this alternative is that, according to the statute, the interest must pass "without any direction on the part of the person making the disclaimer." ${ }^{48} \mathrm{~A}$ gift would seem to violate this provision directly. But if the disclaimant were to give the property to the person who would have received it, had the disclaimer been effective under local law, he would appear to be in technical compliance with the statute, having made merely a

a portion of the asset from creation of the tenancy. I.R.C. $\S 2040$; Treas. Reg. $\S 20.2040-1$ (1958). The Internal Revenue Code also allows income to be returned jointly in a commonlaw jurisdiction, even though the earnings are the sole property of one spouse. I.R.C. $\S$ 6013(a). See R. PauL, The Effect on Federal Taxation of Local Rules of Property, in Selected Studies in Federal Taxation, Second Series 1 (1938).

13 Subsection 3 of section 2518 lends force to this conclusion by requiring that the disclaimant not accept the interest "or any of its benefits." It is difficult to conceive how the disclaimant could meet this condition while retaining legal title to the property. At the very least, creditors would be able to satisfy from the property any claim they may have against the disclaimant, thereby forcing him to "accept" the benefit of the rejected interest.

"The thrust of important parts of the legislative history, see note 39 supra, is to say: tax consequences depend upon the local law of disclaimer; local law varies greatly and unpredictably; the purpose of new section 2518 is to achieve a uniform standard that is to apply notwithstanding a different characterization under local law.

17 See text and notes at notes 133-150 infra.

${ }^{48}$ I.R.C. $\$ 2518(\mathrm{~b})(4)$. To the extent that the person making the gift would have accepted the property and gained some benefit in choosing its eventual owner, such a reading is also in conflict with subsection 3 of the federal statute. See note 45 supra. 


\section{ministerial rather than a discretionary transfer. ${ }^{49}$}

There are several difficulties with this reading of the statute, however. First, it raises severe practical problems the statute does not address, not the least of which is that of designating the proper substitute taker. ${ }^{50}$ More importantly, despite some support for this approach in the background of the 1976 legislation, the legislative history seems to preclude any alternative that permits the original recipient to direct the transfer of the property in any way. ${ }^{51}$ Indeed,

49 In effect, this reading of the statute views the "without direction" language as prohibiting any direction at the discretion of the disclaimant. This understanding would not only resolve the problem posed by subsection 4 , but would also allow the disclaimant to comply with the spirit of the no-acceptance-of-interest-benefits requirement of subsection 3 . If the disclaimant acts promptly he arguably will have "accepted" the property only in the most abstract terms, and his creditors will most likely be unable to move quickly enough to attach his interest. Moreover, since the substitute taker is already determined, the disclaimant will not have received any of the benefit of choosing the ultimate taker.

It should be noted that two states, quite accidently, have already provided a variant of this procedure. In South Dakota and Texas, an ineffective attempt to disclaim will operate as an assignment to a taker substituted by law. S.D. Comprized LAws ANN. \$ 43-4-34 (Supp. 1978) (applies to untimely disclaimer only); Tex. Prob. Code ANN. § 37A (Vernon Cum. Supp. 1978). It is unclear, however, whether this assignment will save the disclaimant from running afoul of the no-benefits condition of the federal statute.

so Just as section 2518 provides no transfer mechanism, it also provides no general rule about substitute takers. This omission could be remedied by turning to state law. Yet because the problem only exists when the state statute does not recognize a disclaimer as valid, the statute ordinarily will not indicate who should be the substitute taker. A rule that merely invokes the law of lapse ignores the conceptual difficulties that would exist in inter-vivos transfer cases. It is certainly unclear where such a rule can be found in the federal provision as it now reads.

st In its General Explanation of the Tax Reform Act of 1976, the Joint Committee on Internal Revenue Taxation explained that

[if] the requirements of [section 2518] are satisfied a refusal to accept property is to be given effect for Federal Estate and Gift Tax purposes even if the applicable local law does not technically characterize the refusal as a "disclaimer" or if the person refusing the property was considered to have been the owner of the legal title to the property before refusing acceptance of the property.

General Explanation, supra note 27, at 590-91 (emphasis added). But not only did the committee not indicate what kinds of transfers that fail technically as disclaimers under local law would satisfy the new section, it later stated that for section 2518 to apply:

[T] $T$ he person must not have accepted the interest or any of its benefits before making the disclaimer. For purposes of this requirement, the exercise of a power of appointment to any extent by the donee of the power is to be treated as an acceptance of its benefits. ... [T] disclaimer as a result of the refusal to accept the property. For purposes of this requirement, the person making the disclaimer cannot have the authority to direct the redistribution or transfer of the property to another person and be treatęd as making $a$ "qualified disclaimer."

Id. at 591 (emphasis added). Although this language is not altogether clear, its very directness as well as the absence of any qualification severely undermines a reading of the statute allowing the disclaimant to direct the property, even in the limited fashion suggested in the text. The stringent treatment of powers of appointment-themselves "interests" for purposes 
Congress considered several statutory alternatives that allowed the disclaimant to direct the property, and it apparently declined to accept any one of them. ${ }^{52}$

of the statute, see section 2518(c)(2); text and notes at notes 56-59 infra, and closely related by nature to the question of directing interests-lends force to this conclusion. Since the no-benefits clause is closely related to the no-direction clause of section 2518 , see notes 48-49 supra, it should not make a difference that the firm rule on powers of appointment occurs in reference to subsection 3 of section 2518 rather than subsection 4 .

For further discussion of these two broad statements in the legislative history, see note 53 infra.

32 Several different proposals for reform of federal disclaimer law were considered during the hearings on section 2518. Among these was a proposal by the American Law Institute that "in order to give maximum freedom in post-transfer rearrangement," Congress

recognize as a disclaimer, if timely action is taken, what may be regarded locally as accepting the interest and transferring it, provided no tangible beneficial enjoyment results from the acceptance. This, in effect, would allow the disclaiming party to direct where the disclaimed interest will go by acting promptly, without being treated as a transferor for transfer tax purposes.

House Comm. on Ways and Means, Background Materials on Federal Estate and Gift TAxation, 94th Cong. 2d Sess. 362 (1976) [hereinafter cited as Background Materials].

That Congress chose not to adopt this course is evident not only in that section 2518 as enacted does not follow the contours of the ALI proposal, but also in that the proposal Congress did follow most closely-that of the American Bankers' Association-explicitly rejected the ALI alternative. The drafting committee of the American Bankers' Association explained that

[the ALI] recommendation has been rejected as being inconsistent with an underlying premise of the Draft that control over property should give rise to tax to the person having such control. The power to redirect constitutes control over the property similar to a general power, and should be treated similarly, whether or not the recipient derives a benefit from the property.

Id. at 605 . It should be noted that the concept of "redirection" mentioned here appears to refer to the discretionary acts of accepting and retransferring the property, not to the ministerial, nondiscretionary direction discussed in note 49 supra.

In adopting the American Bankers' Association approach in almost literal terms, Congress did make one significant alteration in the language of the proposed section. The Bankers' proposal had defined the term "disclaimer" as the "irrevocable and unqualified refusal by an individual in accordance with local law to accept . . . property." BACKGround MATERIALS, supra, at 604 . In the final legislation, the "in accordance with local law" language was deleted and replaced by the requirement in section $2518(\mathrm{~b})(4)$ that "the interest" pass "without direction." This alteration was apparently intended to provide for the case, mentioned in the GENERAL EXPLANATTON, supra note 27, at 590-91, of a failure to comply with the technical requirements of state law. But it may be significant enough, especially in light of the goal of uniformity sought by the Congress, to suggest that the "interest passes" language was adopted to allow the "ministerial-direction" approach suggested in the text.

Indeed, a third proposal considered by the Congress was that of the American Bar Association, see House REPORT, supra note 29 , at $66 \mathrm{n.5}$, which, although rejecting the ALI proposal, presented just such a ministerial-direction option for reform of the disclaimer provisions. Ultimately, however, the evidence indicates that the proposal was not adopted during the consideration of section 2518. The structure of the ABA proposal, see text and note at note 155 infra, is entirely different from that of the American Bankers' Association model and section 2518 as enacted. More importantly, although the clause in the ABA's model statute that embodied the ministerial-direction concept, see Tax Section Recommendation No. 19742, 27 TAX LAW. 818, 823 (1974), could easily have been separated from the larger proposal 
Another reading of section 2518, for which there is support in the legislative history, is to view the statute as applying when the donor of the interest has himself eliminated the need to resort to state law. When the transfer is by deed or will, the instrument of transfer might well specify the disposition to be made in the event of rejection by the designated taker. ${ }^{53}$ Assuming the alternative transfer is precipitated by an act that satisfies the other conditions of the federal rule, ${ }^{54}$ there would be a passing of the rejected interest to another without any directive by disclaimant, and thus a valid disclaimer.

This solution, although sanctioned by the statute, puts an obvious premium on anticipatory planning and drafting..$^{55}$ For this reason, it is difficult to embrace from a policy standpoint. Indeed, the result is almost as objectionable as the old distinction permitting disclaimers of testate but not intestate shares. Under this new solution, only some testate shares (those with specified alternate devises) could be renounced if state law does not recognize the disclaimer as valid. Moreover, the very infrequency with which this solution could be used underscores its limitation as a means of resolving the dilemma posed by section 2518 . Ultimately, it fails to bring uniformity to the treatment of disclaimers in the great mass of cases. As a result, although such a reading is acceptable under the section as constituted, it fails, along with the other readings of the statute, to effect the basic purpose Congress had in mind when it enacted the section.

and incorporated into section 2518 , the present statute bears no evidence of such a clause nor was such language actually discussed by Congress in the course of its consideration. In short, the legislative history strongly indicates that Congress considered, but declined the adoption of the ministerial-direction alternative. For its part, the IRS seems to regard the "interest passes" language of section 2518(b)(4) as merely incorporating the "in accordance with local law" concept of the American Bankers' Association proposal. See Letter Rulings 7803065 and 7830022 , which state that a disclaimer must meet the requirements of local law as well as those of section 2518 .

ss Significantly, this situation-in which the interest passes without direction because of a substitute transfer provided by the donor-fits neatly into the statutory language and reconciles the statements in the legislative history, see note 51 supra, that the disclaimant may not direct a transfer but need not meet all the technical requirements under state law.

s4 The instrument would need to state: "In the event the recipient makes a qualified disclaimer as defined in I.R.C. section $2518, \ldots$. "Theoretically, a state might refuse to recognize a rejection as valid if it fails to satisfy the state's requirements even though it met the conditions in the instrument of trangfer. Such a result seems inconsistent with a broad concept of testamentary freedom and the right to alienate and assign property freely. A state could feel, however, that certainty of result is an important public policy best achieved and promoted through adherence to a state's exclusive method for disclaimer.

ss General preparation for future events is laudatory. The objection made here, of course, is that this planning can only be done by highly skilled technicians who are steeped in knowledge of complex and detailed law. 
3. Powers of Appointment. The requirement that the disclaimed property pass to another person contains an additional threat to the success of the statutory scheme for disclaimers in that the "passing" requirement evidently applies to the disclaimer of a power of appointment. Section 2518(c)(2) provides that a power is to be treated as an interest in the property to which it pertains. ${ }^{56}$ Since an interest in property may be rejected, this apparently means that a power may be disclaimed. ${ }^{57}$ In property law, however, a power of appointment is considered personal to the donee of the power; ${ }^{58}$ when it is disclaimed, the power terminates. Thus, since a disclaimed power does not pass to another person, the requirement of section 2518(b)(4) cannot literally be satisfied.

On the other hand, there is some shifting of interests upon disclaimer of a power of appointment. At the creation of a power, the interests acquired by those persons designated as takers in default are subject to defeat by exercise of the power. If the power is disclaimed, the default takers gain indefeasibly vested interests. ${ }^{.9}$ Perhaps this shifting is adequate to satisfy the policy of section $2518(b)(4)$ even though the disclaimed power itself did not pass to another person.

\section{Timing Problems}

1. Opportunities for Delay. Section 2518(b)(2) provides that a qualified disclaimer must occur within nine months of the transfer creating the interest or in the case of a minor, within nine months of the disclaimant's twenty-first birthday. ${ }^{60} \mathrm{~A}$ disclaimant's failure to meet state timing requirements that are shorter than these strictures $^{61}$ can raise all of the difficulties associated with the "interest passes" language of section 2518(b)(4). Yet, the nine-month period

so I.R.C. $\$ 2518$ (c)(2) ("PowsRs. A power with respect to property shall be treated as an interest in such property.").

${ }^{37}$ Those state statutes that permit the rejection of property coming to the recipient under a power of appointment clearly regard the appointee or the taker in default as the disclaimant. Whether the donee of the power may reject the power itself is left undetermined. See, e.g., Mrch. Comp. Laws ANn. $\$ \$ 554.501,554.503$ (Cum. Supp. 1978-1979); N.C. Gen. STAT. § 31B-1(a) (1976). The omission may simply indicate that disclaimer statutes permit rejection of property passing to the recipient, and a power of appointment is not, strictly speaking, an interest in property. 5 AMrrican LAW OF Property $\S \S 23.1-.5$ (A.J. Casner ed. 1952).

s8 L. Simes \& A. SmITH, LAw of Future INTERests $\$ 943$ (2d ed. 1956). The disclaimer statutes of several states explicitly say that a disclaimed power is extinguished. See, e.g., MD. Est. \& Trusts Code ANN. § 9-201(c) (Cum. Supp. 1978-1979).

3) L. Simes \& A. SMrTh, supra note 58, $\S 1061$. See also id. $\$ \S 1051-1063$ (other terminations of powers).

“ I.R.C. $\$ 2518(\mathrm{~b})(2)$.

" Some of the different state time limitations are discussed in note 36 supra. 
allowed for making a qualified disclaimer decision, seemingly quite reasonable by itself, presents difficulties even more serious than a potential disharmony with state law. The nine months run from the time the interest is treated as a completed transfer under tax law. ${ }^{62}$ At the very least, this principle incorporates into the disclaimer rules all the complexities of determining when a transfer is complete $^{63}$ without any apparent reason for doing so other than to stipulate a time from which the nine-month period begins to run.

Perhaps more importantly, the statute's timing rule appears to extend unnecessarily the time for disclaiming some future interests. For example, the rule permits recipients of future interests in revocable trusts to defer decisions about acceptance or rejection even though donees of irrevocable future interests must decide within nine months. According to the Joint Committee's General Explanation, ${ }^{64}$ moreover, if a property interest is included in the tax base of the transferor's estate, the next taker has nine months thereafter to make the disclaimer decision. As a result, a default taker under a general power apparently may defer his decision until nine months after the donee's failure to exercise, and a remainderman after a retained or revocable life estate may wait until the donor's death plus nine months. ${ }^{65}$ In all of these cases, the delay is permitted even though the future interest is created during the donor's lifetime and, in some instances, may have constituted a completed gift for tax purposes. ${ }^{66}$

The reason for permitting this delay in starting the disclaimer period cannot be that Congress was wary of any uncertainty about the quantity or existence of the interest. Despite similar problems with contingent interests, Congress, expressing hostility to the Keinath result, ${ }^{67}$ refused to accept the long delays that might arise

62 House Report, supra note 29, at 67; General Explanation, supra note 27, at 591; H. Conf. ReP. No. 1515, 94th Cong., 2d Sess. 623-24, reprinted in [1976] U.S. Code ConG. \& AD. NEws 4118, 4261-62 [hereinafter cited as ConfERENCE REPORT].

${ }^{6} 3$ See generally C. Lowndes, R. Kramer \& J. McCord, Federal Estate \& Gift Taxes 702-37 (3d ed. 1974); R. Stephens, G. Maxfield \& S. Lind, Federal Estate and Gift Taxation If $10.01[4]$ (4th ed. 1978).

it General Explanation, supra note 27, at 591; Conference Report, supra note 62, at 623.

${ }^{85}$ Id.

so For example the inter-vivos transfer of a remainder interest with a retained life estate in the donor is a completed gift of the remainder although the retained income interest will cause the entire property to be taxed in the donor's gross estate. I.R.C. $\$ 2036(a)(1)$. One commentator, see J. McCoRD, supra note 31, has asserted that the Conference Committee had in mind only remainder interests subject to alteration by the donor when it referred to the disclaimer period running from the donor's death rather than creation of the interest. He has stated that the Regulations should adopt this more restrictive view of the timing problem.

${ }^{67}$ See note 29 supra. 
from waiting until absolute vesting occurs. In addition, there is always the possibility that a transferee may not know of his interest in property, but the statute does not include any general extension of time to cover such cases. ${ }^{68}$ Good arguments can be made that both lack of knowledge of the interest and uncertainty of its quality and quantity should permit delay in making a decision whether to disclaim. ${ }^{69}$ Rather than acknowledging this conclusion as a general proposition, however, the timing rule permits this delay only in certain situations. The selection of those instances does not conform to any rule that identifies the situations in which delay is reasonable; consequently, the timing rule seems objectionable for both its complexity and lack of purpose.

2. Disclaimers by a Minor. The grace period for a minor's decision to accept or reject gifts, allowing him to disclaim as late as nine months after attaining age twenty-one, is also subject to serious objections. The threshold problem of a young child's disability could be overcome by permitting a guardian to disclaim for the child. ${ }^{70}$ Particularly when it is authorized by statute, the court with jurisdiction over the guardianship should permit a disclaimer by the guardian after a showing that the gift is burdensome. Such an order is purely protective of the minor, thereby falling within the general purpose of guardianship. ${ }^{71}$ At the same time, the original justifica-

" But see Stephens \& Calfee, supra note 41.

" It is unreasonable to expect a refusal to be articulated if the intended recipient is unaware that he has been offered something. Moreover, a meaningful decision can be made only when the exact nature and extent of the gift are known. Some proposals, see UNIForM Disclaimer of Transfers By Will, InTESTACY or Appointments Act $₹ 2$ (b) and Uniform Disclaimer of Transfers UNDER NONTESTAMENTARY INSTRUMENTS ACT \& 2(a), adopt the point at which the taker is identified and the interest indefeasibly vested as the beginning of the time period for a disclaimer of a future interest. The proposals of the American Bankers' Association also adopt this approach, see Background Materials, supra note 52, at 604. A similar provision appears in the UNIFORM PrOBATE CODE \& 2-801(b)(2) (1975). The Code also provides that lack of knowledge of the interest is an overriding circumstance that suspends the running of the time period. Lack of knowledge also suspends the time period in the American Law Institute proposals, ALI, Federal Estate and GifT Taxation 95-97 (1968) [hereinafter cited as ALI STUDY].

70 Normally, a disclaimer is considered to be personal to the recipient. Rock Island Bank \& Trust Co. v. First Nat'l Bank, 26 Ill. 2d 47, 185 N.E.2d 890 (1962). Several model statutes, however, extend the right to disclaim to the fiduciary of an incapacitated person, although they do not permit that right to survive death. UNIrorm PROBaTe CoDE § 2-801(a) (1975). Several states specifically authorize disclaimer by the fiduciary of an incapacitated person. See e.g., Minn. Stat. ANN. \$ 525.532 (West 1975) (disclaimer is permitted with or without court approval); PA. Cons. Stat. ANN. tit. 20, § 6202 (Purdon Supp. 1978-1979) (permitted only with court approval).

7 A number of courts have authorized guardians of incapacitated persons to make gifts on the theory that, in a broad sense, some gifts are beneficial to the ward. See In re duPont, 41 Del. Ch. 300, 194 A.2d 309 (1963); Ex parte Whitebread, 35 Eng. Rep. 878 (1816); UNIFoRM 
tions for recognizing a disclaimer-to permit escape from burdensome gifts and to permit a broad freedom of decision-simply do not demand that matters be held in abeyance for as long as twenty-one plus years. As suggested, a court can fulfill the first policy, that of avoiding burdens, even while the disability of minority exists. The extended wait to age twenty-one is too high a price to pay for preserving the minor's right to reject arbitrarily a gift that is beneficial or at least not harmful. The grace period in such a case does little more than allow a long delay in deciding if the gift is needed or should be rejected because there is access to enough other wealth. Thus it seems that the grace period opens broad, perhaps unwarranted, vistas for tax planning. ${ }^{72}$

A grace period for minors is not found in typical state disclaimer laws ${ }^{73}$ so that this feature may be one more source of conflict between the two levels of law, precipitating the problems and uncertainties discussed earlier. The hiatus is also difficult to reconcile with section $2518(\mathrm{~b})(3)$ 's requirement that disclaimer precede acceptance of benefits. May a minor who is given an income interest enjoy the income until age twenty-one and then make a disclaimer? ${ }^{74}$ If not, assuming a guardian and a court would hesitate to disclaim in view of the grace period, is the minor practically foreclosed from disclaiming? Should draftsmen anticipate this uncertainty and authorize trustees to accumulate all income payable to minors in order to negate any assertion of acceptance that might prevent the minor beneficiary from disclaiming upon reaching twenty-one? In short, the grace period, seemingly an innocent if not salutary provision, ${ }^{75}$ creates considerable, far-reaching problems.

ProBate CODE § 5-408(3) (1975). It would appear that avoidance of unwanted burdens would provide an even stronger justification for action by the guardian.

72 See, e.g., text and notes at notes 25-29 supra and notes 76-130 infra.

${ }^{73}$ Apparently only two states suspend the running of the disclaimer period until the donee attains the age of majority. Rhode Island permits a person who was under a disability at the time of the gift to disclaim within six months after removal of the disability. R.I. GEN. Laws § 34-5-9 (1969). South Dakota has a similar provision with a deadline of nine months after removal of the disability. S.D. CoMP. LAws ANN. § 43-4-31.1 (Supp. 1978).

"Although acceptance of a gratuitous benefit is not the same as entering into a contract, nevertheless if there is acceptance, a minor might be able to disaffirm, as in contract law, upon reaching majority. If disaffirmance is allowed, the minor may be required to repay the income or other benefit received, at least to the extent he still has the property. See generally 2 S. Williston, Law of Contracts \$§ 222-239 (3d ed. 195̧9).

${ }^{75}$ The provision is praised for its practicality in J. McCorD, supra note 31, § 5.28(3). Professor McCord believes a court will not often grant approval for disclaimer because the rejection runs counter to the duty to conserve and protect the ward's property. If the primary motive is tax planning this deduction is logical for the simple reason that tax rates are not yet 100 percent. A court should not, however, be reluctant to allow rejection when there is a genuine burden associated with acceptance of the gift. 
Admittedly, section 2518 is not responsible for all our present difficulties. Indeed, there was nonuniformity in the tax treatment of disclaimers before its enactment. And, necessarily, there will be conflict in any attempt to change the tax results of situations such as those in Hardenbergh and Keinath, bottomed as they were on local property law. But the new rules were enacted with the promise of resolving the old difficulties, and it is striking not only that they failed to achieve uniformity, but also that they have created new conflicts and complexities for understanding the law of disclaimers. These problems raise questions about the advisability of having enacted section 2518, questions that become even more troubling when we turn to the section's effect on the planning stages of gift and estate transactions.

\section{Section 2518 and Estate Planning: Unjustified Complexity}

Notwithstanding the conflicts, uncertainties, and lack of uniformity created by the new statute, it is often possible to make a disclaimer that is qualified under both state and federal law. As a result, it is possible to redirect gifts and indeed to redesign an estate plan through use of post-mortem disclaimers. These possibilities will, no doubt, provide estate planners with a strong incentive to draft with an eye on the requirements of section 2518 and to utilize all permissible avenues under that section for obtaining tax benefits. Careful consideration of the disclaimer provisions will help preserve flexibility in the choice of dispositive patterns and tax consequences for the longest possible period. At the very least, draftsmen will provide alternative takers for cases of rejection in order to exploit whatever new freedom the federal law has to offer.

Section 2518 may well have opened up more opportunities for creative drafting than first anticipated. Such opportunities of course raise long-term questions about the acceptability of unintended tax breaks, but a more immediate concern is that the new section may inject a new dimension of complexity into estate practice. Clearly, the new legislation raises difficult problems of interpretation at the drafting stage and poses complex questions about tax minimization in the post-mortem period. These concerns seem particularly pressing in light of section 2518's failure to attain its goal of uniformity. As will be suggested, however, they seem substantial enough to raise doubts about even a perfected statute.

\section{A. Nature of an Interest}

Planners and taxpayers first confront the complexity and un- 
certainty that inheres in section 2518 when considering the statute's focus on an interest in property as the subject of the disclaimer. ${ }^{76}$ The meaning of that focus is open to several interpretations, each dictating different drafting techniques. Since ownership of property can be fragmented into many component parts, reference to "an interest in property" would seem to mean a constituent element of the property less than the whole. Although the statutory language does not say explicitly that a partial disclaimer is permitted, in the sense that a recipient may reject part of the gift while accepting another part, reference to "an interest" could implicitly sanction partial disclaimers.

It is possible, however, to read the statutory reference to mean that the beneficiary may reject only the whole of whatever is given and may not fragment that interest into further subdivisions, one or more of which he accepts. The provision of subsection (c)(1), allowing disclaimer of an undivided interest, seems to support this latter construction, suggesting that rejection of an undivided portion stands as the sole exception to the need to take the gift in whole or reject it in whole. ${ }^{77}$ In addition, interpreting section 2518 so that rejection of an undivided portion is the only exception to the requirement of full acceptance or full rejection is arguably compatible with the common-law rule of disclaimer and thus is consonant, although not fully congruent, with the requirements of some state laws..$^{78}$

"Q "Qualified disclaimer" means ... refusal . . . to accept an interest in property .... if -

(1) such refusal is in writing,

(2) such writing is received . . . not later than . . 9 months after the later of -

(A) the date on which the transfer creating the interest in such person is made, or

(B) the day . . . such person attains age 21 ,

(3) such person has not accepted the interest or any of its benefits, and

(4) as a result of such refusal, the interest passes [to donor's spouse or to another without any direction by disclaimant].

[(c)]

[(1)] A disclaimer with respect to an undivided portion of an interest . . . shall be treated as a qualified disclaimer of such portion of the interest.

[(2)] A power with respect to property shall be treated as an interest in such property."

I.R.C. $\S \S 2518(b), 2518$ (c) (emphasis added).

77 Professor McCord argues that the requirement contained in I.R.C. section 2518(b)(3) that a qualified disclaimer precede acceptance of any benefits may prevent partial disclaimers. J. MCCoRD, supra note $31, \S 5.28(4)$. That requirement, however, also focuses on "the interest," which itself could be less than the whole gift.

${ }^{78}$ When a single gift is made, the recipient may not divide it, accepting the beneficial and declining the burdensome aspects of the gift. On the other hand, if the gifts are truly separate, the beneficiary may pick and choose. See note 37 supra. The rule suggested in the 
However logical it might be, the foregoing position is difficult to maintain and may ultimately prove to be incorrect, or at least misleading, in the face of the most difficult questions posed by section 2518. Cases in which the donor separates the gift of a single asset into various present and future interests, or other beneficial rights, are particularly troublesome. As an initial example, suppose a settlor creates a trust, stipulating that income is payable to $X$ for life, corpus at $X$ 's death to $Y$. The settlor also authorizes the trustee to invade the corpus for $X$ 's health and support needs. $X$ is given two different present beneficial interests. Under disclaimer laws that recognize partial rejections, $X$ is clearly able to disclaim either interest while retaining the other. ${ }^{79}$ Now consider a case in which $D$ transfers Blackacre to $A$ for 10 years, then to $B$ in fee if living, otherwise to $A$. Under the law of several states, as noted, $A$ could not reject the term for years without also rejecting the contingent remainder ${ }^{80}$ Section 2518 does not yield precise responses in these examples. Each of the interests given to $X$ in the first example and to $A$ in the second example can be poured into the crucible of section 2518 and found to satisfy its requirements. Thus, when the donor states separate interests rather than leaving to the donee the task of carving off and rejecting a separate part, it is arguable that the donee can disclaim one or more of the separately stated interests. ${ }^{81}$

This conclusion certainly would encourage draftsmen to divide gifts into many components. Such a tax-law doctrine of separability may be practical, since it comports with the law of many states and offers a rule for stating when partial disclaimers are permitted, but

text follows these lines. Authority to disclaim an undivided interest comports with the first proposition-because joint tenants or tenants in common share all burdens and benefits in the property-if not the second.

The relationship of such a rule to state statutory law is less clear, since, as has been indicated, the state statutes, though varying considerably, generally permit partial disclaimers. These statutes are generally silent about what constitutes a partial disclaimer, and some states have limitations on partial rejections or refuse to permit a donee to reject a present interest in property while accepting a future interest. Nevertheless, the suggested reading of the federal statute would probably result in considerable incongruity between state and federal law.

"Whatever deficiencies are present in the statutes, it seems that allowance of partial disclaimer means at least that the donee can pick and choose among separate gifts. Of course, there could be a question whether different interests in the same property truly are separate gifts, but the allowance of partial disclaimers would suggest that a single gift could be accepted in part only. See note 37 supra.

See note 37 supra.

st If is of course possible to disclaim an undivided portion on these facts: $A$ could, for example, reject an undivided one-third of both the term for years and the contingent remainder. The question, however, is whether the undivided portion route is the only acceptable partial rejection. 
it also would be unfortunate. Practicality aside, there is no sound policy reason for permitting partial rejections when the donor separately states the components, but refusing, except in the case of undivided portions, to allow them otherwise. ${ }^{82}$ Indeed, if Congress actually intended rejection of an undivided interest to be the sole means of making a partial disclaimer, the consequence of this rule would be an emasculation of the statutory intent. More importantly, a major consequence of this reading of the statute would be an undue premium on the use of sophisticated advance planning.

Just how great this premium may be becomes clear from the following example: Testator bequeaths to his son $L$ until age 65, then to testator's wife if living; if wife is not then living, to $L$ for the balance of his life, remainder as $L$ appoints by special inter vivos power of appointment, if that power be rejected, then as $L$ appoints by general testamentary power, in default to $M$. This scheme looks bizarre and served little purpose before the adoption of section 2518 . By inserting a contingent life estate commencing at $L$ 's age $65, T$ has managed to separate what could have been a single life estate into two distinct interests, thereby permitting $L$ to decide whether to take an income interest commencing immediately or to reject it while keeping the right to have the income flow begin at the time of normal retirement. ${ }^{83}$ The separate statement of an alternative power may also permit $L$ to decide how much control, if any, he wishes to retain over ultimate disposition of the property, with the options often carrying different tax consequences. ${ }^{84}$ Clearly, then,

82 It could be argued that an analogy to the common-law doctrine of separability, which permits a court to uphold a disposition against a charge of violation of the Rule Against Perpetuities, provides such a justification. That doctrine holds that, if a testator has stated a disposition in two ways, one violating the Rule and one complying with the Rule, the arrangement is valid if the facts of the valid disposition actually occur. The doctrine is inapplicable, however, if the testator has failed to separate the alternatives. Requiring the separation by the testator is necessary to prevent a court from concocting alternatives in hindsight in order to uphold the disposition on facts that actually occur. See L. Simes \& A. Smiтh, supra note 58, \$§ 1257-1261. Similarly, in the disclaimer context, it might be useful to require a donor to make the separation for otherwise the recipient could carve up the gift and make his own selection of partial interests. But the separability rule looks primarily to preserving the testator's basic plan of distribution and restraining judicial manipulation in the face of a stringent rule on remote interests. The disclaimer rule, on the other hand, serves no comparable policies while creating an inducement for the testator to develop a series of artificial interests, designed to allow the donee to avoid taxes, through the use of artful estate planning.

*s This device would not work under state statutes that interpret a rejection of a present interest in property to imply disclaimer of a future interest in the same property. See note 37 supra.

$"$ As written $L$ has a nontaxable power of appointment. If he rejects it he obtains a taxable power of appointment. The rejection may be valid under state law, thereby causing a shift to the general power, but not qualifed under section 2518 because $L$ continues to have the ability to direct ultimate disposition of the property. See note 101 infra. The failure to 
section 2518 provides a strong incentive for estate planners to concoct strings of partial, separate interests in property, which will permit and facilitate the recipient's selection of the interest he wishes to retain or reject. Considerable time and expense, no doubt, will be devoted to developing the proper order for such strings of interests and ensuring their technical compliance with the statutory requirements.

\section{B. Flexibility and Spousal Disclaimer}

Even if section 2518 eventually is construed to limit partial disclaimer to cases involving undivided portions, and even if that construction discourages concoction of unusual strings of separately stated interests, the section still offers considerable flexibility to estate planners and recipients of property. A simple illustration suffices. A client with present net worth of $\$ 150,000$ and some uncertain potential for growth requests a will that provides adequately and appropriately for his wife and children. So long as his wife has little or no property and the client's assets do not exceed $\$ 175,000$ to $\$ 180,000$, there is no need for sophisticated, marital-deduction estate planning. ${ }^{85}$ The planner might rely on the classic simple will-everything to his wife if living, otherwise to the children equally - with the knowledge that availability of the disclaimer provides protection against the adverse tax consequences that might arise if the client's estate grows significantly. If the market value of the adjusted gross estate at death is $\$ 300,000$, the spouse could disclaim an undivided portion, rejecting as much as $\$ 125,000$ or $125 / 300,{ }^{86}$ in order to shift that portion to the children and avoid (or

qualify under section 2518 has no adverse consequences, however, because at worst $L$ has released a nontaxable power and hence has not undertaken a taxable transfer. See I.R.C. $\S$ 2514.

is The exemption equivalent of the unified transfer tax credit allowed under I.R.C. section 2010 is $\$ 175,625$ for decedents dying after December 31, 1980. The textual example presupposes that lifetime transfers have not consumed part of the unified credit.

s Either a fractional interest or a specific dollar amount should qualify as an undivided portion of the whole. Alternatively, a spouse may want to accept or to disclaim payment in terms of a fixed amount per month. The Supreme Court has held that, for purposes of qualifying for the marital deduction, a definite monthly payment can be projected into a "specific portion" by use of an assumed rate of return. Northeastern Pa. Nat'1 Bank v. United States, 387 U.S. 213 (1967). It would seem that fixed payment can also qualify as an undivided portion in a similar fashion. It should be noted, however, that in construing the term "undivided portion" as it pertains to the income tax deduction for charitable contributions of partial interests in property, the Internal Revenue Service has stated that "[a]n undivided portion . . . must consist of a fraction or percentage of each and every substantial interest or right owned by the donor in such property." Treas. Reg. $\S 1.170 \mathrm{~A}-7(\mathrm{~b})(1)(1972)$ (emphasis added). 
minimize) estate taxation in her gross estate. ${ }^{87}$

Reliance on the mechanism of disclaimer presents considerable risks and disadvantages as a planning tool, ${ }^{88}$ and it is unclear why the tax law should countenance or encourage its use. It is thus important to ask what policy is promoted by allowing a surviving spouse to adjust the decedent's estate plan to achieve the optimum tax results, with the adjustment itself being permitted on a tax-free basis. The entire interest received by the spouse appears beneficial; by definition ${ }^{89}$ it is a part of the net estate, free of claims by the decedent's creditors and in excess of mortgages or other liens. Nor is it significant that some potential future tax consequences at the spouse's death might be labelled burdensome..$^{90}$ They are simply not relevant to characterizing the interest at the time of the disclaimer.

The old justification for recognition of a disclaimer-that the donee should be permitted to escape from burdensome gifts-does not seem persuasive in these circumstances. The only burden escaped in most of these cases is a potentially higher tax bill. Of course, it is possible to take refuge in the notion that only the recipient should decide what is a benefit and what is a burden. Thus, the policies of permitting independent evaluation and independent, even arbitrary, decisions to reject might be advanced. ${ }^{91}$ But because a disclaimer gives rise to consequences that may have an impact far beyond the individual disclaimant, policies focusing on the disclaimant alone give an incomplete picture of the interests at stake.

${ }^{87}$ This shifting of the interest may be good tax planning, but the result may be terribly impractical, since the spouse may require the income from the entire estate for living needs and the corpus for security.

\$ The surviving spouse may not survive long enough to consider and make a disclaimer or the spouse could survive but be incompetent and unable to disclaim. See note 70 supra.

${ }^{83}$ I.R.C. section 2056(c)(2)(A) defines the adjusted gross estate as the gross estate less the debts, liens, funeral expenses and expenses of administration allowable as deductions under I.R.C. section 2053, and losses deductible under I.R.C. section 2054, subject to a further adjustment if the decedent owned community property.

90 Benefit is here used to mean primarily economic value. If tax considerations are the motive for disclaimer, then, because tax rates are not yet 100 percent, the refusal is a rejection of a beneficial gift. As has been noted, see text at notes 9-17 supra, commentators seem to agree that today tax considerations are the dominant motive for disclaimers. E.g., Finnell, Disclaimers and the Marital Deduction: A Need for Adequate State Legislation, 21 U. FLA. L. REv. 1, 1 (1968); Newman \& Kalter, supra note 17, at 829; Roche, supra note 17, at 20; Note, Taxation: Disclaimer Under Federal and Minnesota Law, 51 MnN. L. Rsv. 907 (1967). Of course, it may be asserted that the obligations and responsibilities of ownership are themselves burdensome. Note, supra, at 908 . Thus, whatever the net economic value of the gift, a recipient should be permitted to refuse it. This argument is, of course, a rephrasing of the principal common-law justification for recognizing disclaimers. Although perhaps valid, such considerations operate infrequently, often merely rationalizing the far more dominant role that tax considerations have played in the disclaimer decision.

"See text at notes 7-17 supra. 
Moreover, to the extent that the relation-back doctrine is given effect, these policies provide ready avenues for minimizing transfer taxes and thus collide directly with the clear public policies embodied in these taxes. ${ }^{92}$

It is particularly important to note, that the general policy of allowing a taxpayer to arrange his affairs in order to minimize his taxes $^{93}$ has little application here. In the context of transfer taxation, it is one thing to permit and encourage owners of property to arrange their dispositions in ways that minimize taxes, and quite another to permit and encourage a potential recipient of property to rearrange, at least in part, a gift (and the donor's plan) in order to reduce taxes still further. The freedoms to assign and alienate, create interests, and select donees subsist in the concept of ownership and justify the broad power in the donor. Logically, however, the donee who refuses ownership is not in a similar position and should not be able to take advantage of these policies.

Finally, it should be noted that, contrary to appearances, the disclaimer device does not really reduce the premium on planning in this context.94 There is still a premium on seeking and receiving timely, sophisticated advice; the disclaimer has in reality only shifted the point in time when expert advice must be obtained. Moreover, that postponement is itself only available when local state law recognizes a qualified federal disclaimer and in doing so provides an alternative taker of the property. In states that fail to validate the disclaimer, advance planning and drafting are necessary to provide expressly for an alternative mode of disposition to take effect in the event of rejection. ${ }^{95}$

When planning is necessary or resorted to, the 1978 amendment of section 2518(b)(4), providing special rules for disclaimers by spouses, raises additional concerns. To return to the previous example: if our hypothetical client has a sufficiently large collection of assets to justify tax-motivated estate planning from the outset, the disclaimer also has a role to play. Interspousal estate planning commonly utilizes two trusts. ${ }^{98}$ The basic marital trust is designed to receive assets qualifying for the estate-tax marital deduction. The

12 See text and note at note 192 infra.

s See Helvering v. Gregory, 69 F.2d 809, 810 (2d Cir. 1934) (L. Hand, J.), aff'd, 293 U.S. 465 (1935) ("Any one may so arrange his affairs that his taxes shall be as low as possible; he is not bound to choose that pattern which will best pay the Treasury; there is not even a patriotic duty to increase one's taxes.").

" Contra, ALI Study, supra note 69, at 39-40; Uniform Probate Code § 2-801 \& comment (1975).

's See text at note 54 supra.

* T. Shafrer, Planning and Drafting Wills and Trusts 263-69 (2d ed. 1978). 
trust meets the requirements for this deduction by stipulating that all its income shall be paid to the spouse for life and by conferring upon the spouse either an inter vivos or a testamentary general power of appointment. ${ }^{97}$ The balance of the decedent's assets pours into a so-called residual trust that typically specifies the wife as income beneficiary and the children or issue as remaindermen.

Good planning would use a formula clause to allocate to the marital trust the exact value of assets necessary to secure the optimal marital deduction for the particular decedent's estate..$^{98}$ The testator or attorney, however, might prefer to allocate identified assets, exact amounts of money, or specific fractions to the maritaldeduction gift, leaving the possibility that the value of the marital gift at death would exceed the ideal amount of marital deduction. Enter the disclaimer. The surviving spouse can cut back the value of the marital gift by refusing to accept the undivided portion that represents the unwanted excess. ${ }^{99}$ Under the typical estate plan, that rejected portion will pass to the residual trust of which the disclaimant is an income beneficiary. To be sure, the interest passes according to an alternative arrangement stipulated by the donor. But it is striking that although the disclaimant will receive benefits from the disclaimed property, the amendment to section $2518(\mathrm{~b})(4)$ in the Revenue Act of $1978^{100}$ expressly recognizes the disclaimer. ${ }^{101}$

"1.R.C. $\S 2056(\mathrm{~b})(5)$.

is T. ShafFer, supra note 96, at 279-83.

" See note 86 supra.

100 See note 5 supra.

101 The typical residual trust into which the disclaimed portion passes often gives the spouse a special (nontaxable) power of appointment in addition to the income interest. Apparently, the disclaimer would not qualify under section 2518 if such a power were present. The Joint Committee Explanation of the 1976 Tax Reform Act stated, in reference to the requirement that the disclaimed interest pass to another, "the person making the disclaimer cannot have the authority to direct the redistribution or transfer of the property to another person and be treated as making a "qualified' disclaimer." General Explanation, supra note 27, at 591. The explanation to the Technical Corrections Bill of 1977, which contained the proposal that eventually amended section $2518(b)(4)$ stated:

The bill provides that, where a surviving spouse refuses to accept an interest in property, the disclaimer will be valid although the surviving spouse receives an income interest with respect to the property if the income interest does not result from any direction by the surviving spouse and the disclaimer is otherwise qualified.

H.R. REP. No. 700, 95th Cong., 1st Sess. 82 (1977). See also S. REP. No. 745, 95th Cong., 2d Sess. 96-97 (1978).

It would appear that this legislative history means the residual trust can provide the spouse with only an income interest and not with a special, nontaxable power of appointment. Consider the results of a contrary conclusion. The unwanted portion of the property could be shifted from a trust in which the disclaimant-spouse has a life estate plus a general power of appointment to one in which the disclaimant has a life estate plus a special power of appointment. A spouse who has refused that portion of the gift could still enjoy its income for life and then direct the ultimate disposition of the corpus at death. The only change would be 
It is possible that a postmortem shifting of interests is more tolerable here than in the simpler hypothetical because the substitute disposition was prearranged by the decedent rather than triggered solely by the disclaimant. The impact of the rule, however, is to encourage dispositions to the spouse with a postponement of the decision regarding the exact amount of the disposition. ${ }^{102}$ That decision, residing in the recipient, will determine both the nature of the property interests and the mix of tax consequences in a manner far beyond that justified by the policy of giving full rein to the donor's ownership wishes. More importantly, the 1978 amendment is in conflict with the property-law rule that a disclaimer in part cannot reject the burdens of an interest while accepting its benefits. ${ }^{103}$ Yet the legislative history does not supply a justification for this exception to the rule. Although the 1978 amendment clarifies the statute and may serve some policies related to spousal dispositions, the exception created is so fundamental a departure from ordinary disclaimer practice that it should not have been adopted without a thorough consideration of its advantages and disadvantages.

The desirability of a disclaimer by the surviving spouse is of course not limited to cases in which the estate plan has funded the marital share with more than the maximum value allowable as a deduction from the decedent's estate. It can also be employed advantageously when the spouse has assets of his or her own, making it beneficial to reject part of the gift from the decedent in order to

the shifting of assets from a trust whose value will for tax purposes be included in the disclaimant-spouse's gross estate at death to a trust that by-passes that estate. The shift would be both elective and tax free.

It could be argued, in favor of permitting the disclaimant to hold a special power under the alternative transfer, that the property initially passes without any direction by the disclaimant. Moreover, the spouse was arguably the recipient of two separate interests, an income interest and a power. There are, in addition, substantial differences between the new power in the alternative gift and the rejected power. For example, the substitute power may be exercisable only inter vivos and it has a narrower group of permissible objects. But, inasmuch as the disclaimant would still have considerable ability to dispose of the remainder, it seems anomalous to say the passing requirement is satisfied by the termination of a power if another power in the disclaimant is substituted for the terminated one. Allowance of this disclaimer technique seems also to violate the firmly embedded tax rule that the donee of a general power cannot release only the right to appoint to himself, his estate or creditors, thereby converting a taxable power to a nontaxable one. See Treas. Reg. $\$ 20.2041-3(d)(1)$ (1958). Although the tax rule speaks of release rather than disclaimer, it cannot be gainsaid that the effect is the same: the donee was given a general power, took action, and wound up with a nontaxable power.

10 The encouragement is being given already, see McCue, Disclaimers: A Survey of I.R.C. Section 2518 and the Illinois Disclaimer Statute, 1978 Irt. L.F. 395, 407; Moore, Drafting in Anticipation of Disclaimer, in 11 U. Mumi Inst. Est. Plan. 9-5 to 9-14 (P. Heckerling ed. 1977).

is See note 37 supra. 
equalize the decedent's and the survivor's estates. ${ }^{104}$ The Internal Revenue Service is currently engaged in litigation over the validity of certain marital-deduction formula clauses that equalize the two estates without aid of a disclaimer. ${ }^{105}$ It appears that, quite accidently, the present disclaimer route offers a mechanism that is safe from challenge for accomplishing the same tax objective. ${ }^{106}$

\section{Generation-Skipping Arrangements}

Disclaimers can also be used to garner tax advantages in generation-skipping arrangements. ${ }^{107}$ Again, the section encourages planners to draft complex dispositive schemes that permit recipients to choose among alternatives through the disclaimer mechanism. The key to tax advantage in this context is that, under a generation-skipping arrangement, the nine-month time period for a disclaimer decision commences with each taxable termination or taxable distribution. ${ }^{108}$ Since these events do not occur at the crea-

16 If the total tax paid by both the husband's and the wife's estates is computed, the lowest amount will be due if the two estates are equalized. This result derives from a progressive rate structure. Even though the lowest amount of tax is payable when the estates are the same size, a decision to equalize may not be the best choice. It may cause more tax to be due on the death of the first to die, and the survivor's loss of future income from this additional tax paid may be significant over the survivor's lifetime. For analysis of decisions to equalize, see J. Casner, Estate Planning 1240 (3d ed. Supp. 1978); T. ShafFer, supra note 96 , at 289.

105 The Service lost its challenge to the validity of an equalization clause in Estate of Smith v. Commissioner, 565 F.2d 455 (7th Cir. 1977), aff'g 66 T.C. 415 (1976), nonacq. 197821 I.R.B. 5. The Tax Court has recently reaffirmed its position in Estate of Meeske v. Commissioner, 72 T.C. No. 7 (1979) and the same issues are again before it in a third case, Estate of Laurin v. Commissioner, [1979] 38 TAX CT. MEM. DEc. (CCH) 644 (April 16, 1979). Appeal in the two latter cases apparently would be to the Sixth Circuit.

16 The disclaimer mechanism, of course, has the perils that arise from uncertainty over the scope of section 2518 and the clash between state and federal requirements for a valid disclaimer. Moreover, as indicated in note 88 supra, the surviving spouse might be unable to make a disclaimer. Thus, the marital-deduction formula clause, if valid, would be a more certain route.

107 Under Chapter 13, I.R.C. $\$ \S 2601-2622$, enacted as part of the Tax Reform Act of 1976, certain dispositive schemes benefiting persons in two or more generations that are younger generations than that of the transferor are subjected to a new tax when the property is distributed to a beneficiary who is in a younger generation than another beneficiary of the scheme. The tax is meant to approximate the tax payable by the skipped beneficiary had a transfer been made to him or her followed by a re-transfer to the actual recipient. For explanations of the new law, see R. CoveY, Generation-Skipping Transfers in Trust (1976); Bloom, The Generation-Skipping Loophole: Narrowed, but Not Closed By the Tax Reform Act of 1976, 53 Wash. L. REv. 31 (1977); Dodge, Generation Skipping Transfers After the Tax Reform Act of 1976, 125 U. PA. L. REv. 1265 (1977); Stephens \& Calfee, supra note 41, at 453.

105 H. REP. No. 1515, 94th Cong., 2d Sess. 607, 617 (1976), reprinted in [1976] U.S. CoDE Cong. \& AD. News 4118, 4255-56. I.R.C. section 2518(b)(2)(A) speaks of the nine-month time period running from creation of the interest. But, as noted in this conference report, the law 
tion of the arrangement but rather at the times when actual distributions are likely to be made, ${ }^{109}$ recipients are permitted the luxury of delaying, until possession and enjoyment are about to begin, the decision whether to accept or reject. ${ }^{110}$

Generation-skipping schemes are often built into the marital and residual trusts found in typical estate plans. ${ }^{11}$ The marital trust will articulate the scheme in the default provisions that take effect in the event the spouse fails to exercise the general power of appointment. ${ }^{12}$ This default clause may provide, for example, life estates in children, with ultimate distribution to their issue upon termination of the life estates. ${ }^{113}$ Since the marital trust will be in the spouse's (parent's) gross estate, ${ }^{114}$ apparently a child can wait until that taxable transfer (the death of the surviving spouse) to decide whether to disclaim. A disclaimer at that point would precipitate a transfer to the next generation, treated under the relation-back theory as coming from the parent who was the beneficiary of the marital trust and, as a direct transfer, not subject to the provisions

views that interest as created at the time a taxable transfer occurs. If the recipient is then under age twenty-one, the period for making a qualified disclaimer is extended to nine months after attaining age twenty-one, I.R.C. $\$ 2518(\mathrm{~b})(2)(B)$. As noted, state law seemingly must also permit a disclaimer within these time periods if the requirement of I.R.C. section $2518(b)(4)$ is to be satisfied.

16 A taxable distribution, defined in I.R.C. section $2613(a)$, is a payment out of corpus during the existence of the trust or trust equivalent to a younger-generation beneficiary, if that payment skips over an older beneficiary. A taxable termination, defined in I.R.C. section 2613(b), is essentially a termination of the interest of an older beneficiary in a trust and a shift of that interest to a younger beneficiary. Such an event may or may not result in an actual distribution of property to the new taker.

110 If no actual distribution is to occur upon a taxable termination, the recipient may have to make a disclaimer decision earlier. But the recipient is still much more certain of the nature and extent of his interest and should have much more information that will influence the decision (family situation, outside wealth, etc.) than he likely had available at the creation of the arrangement.

II' T. ShaFrER, supra note 96 . The marital trust contains property that qualifies for the marital deduction in the decedent-transferor's estate. As used here, that term means a trust complying with I.R.C. section 2056(b)(5) by giving to the spouse all income plus a general power of appointment over corpus. The residual or family trust contains that portion of the estate not needed to obtain the optimal marital deduction. Income and corpus may be payable to the spouse or to the issue or both. In addition, the spouse may (but need not) have a nontaxable power of appointment over the corpus.

112 The presence of default provisions does not destroy the qualification for the marital deduction under the income-plus-general-power-of-appointment exception to the terminable interest rule. Treas. Reg. $\$ 20.2056(\mathrm{~b})-5(\mathrm{~g})(2)(1958)$.

${ }^{113}$ This is a generation-skipping arrangement since the children and grandchildren, or more remote issue, represent beneficiaries at two or more generations that are younger generations than that of the transferor of the property. I.R.C. $\$ \$ 2611(\mathrm{~b}), 2611(\mathrm{c})$.

i' Possession of the general power of appointment requires inclusion of all of the property to which the power pertains. I.R.C. $\$ 2041$. 
of the generation-skipping transfer tax. ${ }^{115}$ Indeed, none of the exemption of $\$ 250,000$ per deemed transferor for distributions to grandchildren would need to be utilized. ${ }^{116}$ The availability of the undivided-portion disclaimer ${ }^{117}$ permits the child to fine tune his decision, keeping that portion of the trust that will be sheltered under this $\$ 250,000$ exemption and rejecting the excess so that it too may pass outside the reach of the new transfer tax.

Focus now on the portion of this trust in which the child does accept his life estate. At the child's death, a taxable termination occurs. ${ }^{118}$ Within nine months thereafter, the next recipient, a grandchild, might disclaim with very desirable tax results. This disclaimer-coming perhaps fifty, sixty, or more years after the arrangement is established-would permit the grandchild to be bypassed (wholly or only on an undivided portion) and, under the theory of relation back, a direct transfer to be made to his children (great-grandchildren of the original transferor). A tax would be imposed on this generation-skipping transfer, ${ }^{119}$ but it might be computed with the grandchild rather than the child as deemed transferor, ${ }^{120}$ a result that would be beneficial because of the difference in rate brackets and method for computation of the tax. ${ }^{121}$

115 See House REPORT, supra note 29 , at 47.

III I.R.C. sections $2613(a)(4)(A)$ and $2613(b)(5)(A)$ exempt from the definitions of both taxable distribution and taxable termination amounts transferred to grandchildren of the original transferor. The maximum is $\$ 250,000$ per "deemed transferor," i.e., parent of the grandchildren.

117 I.R.C. $\$ 2518$ (c)(1). So long as an undivided portion is treated as a separate interest in property, the disclaimant has not accepted any benefits of that interest. Consequently, although the disclaimant may have accepted the other undivided portion, there is a direct (i.e., nongeneration-skipping) transfer of the rejected portion.

IIs I.R.C. $\$ 2613(b)(1)$.

iv The transfer consists of the termination of the child's interest. The disclaimer merely identifies the great-grandchild rather than the grandchild as the recipient of the next interest.

120 The "deemed transferor" is the person whose position in the unified transfer-tax system is utilized to compute the tax on the generation-skipping transfers. Under the definition of "deemed transferor" in I.R.C. section 2612, a parent of the transferee is the deemed transferor unless the parent is not a younger-generation beneficiary of the trust and someone else in the ascending line who is related to the trust grantor is a younger-generation beneficiary. If, in the textual example, the grandchild disclaims an undivided interest, he still is a younger-generation beneficiary and eligible, therefore, to be the deemed transferor. The Internal Revenue Service, however, may require that status as a beneficiary-for purposes of qualifying as the deemed transferor-be determined by reference to the disclaimed interest. If so, then arguably the child rather than the grandchild is the deemed transferor.

i21 Since the grandchild is younger than the child, he has likely made fewer taxable gifts, and is therefore in a lower position in the progressive rate structure. Moreover, since the child has now died, a finding that the child is the deemed transferor would mean that the generation-skipping transfer will be added to the child's gross estate (augmented by adjusted taxable gifts) under I.R.C. sections 2001 and 2602 , to be taxed at the highest marginal rate applicable to the child. If the grandchild is treated as the deemed transferor, this transfer is 
Employment of disclaimers at crucial junctures may, in a similar manner, increase the utility of the typical residual or family trust as a generation-skipping vehicle. Assume, for example, that a testator provides income to be paid to spouse for life, then to a child for life, remainder to a grandchild, and that he authorizes the trustee to invade the corpus as needed for the beneficiaries. Assume further that he states that he encourages liberal use of the invasion power to build up the grandchild's estate so long as it appears the spouse has adequate security and that provisions are otherwise made or available for the child. With the exhortatory language, the testator has only slightly embellished a very common design for the residual trust. ${ }^{122}$ If the child disclaims all interest in having the power of invasion exercised in his behalf ${ }^{123}$ (or if the testator refrains from conferring that power on the trustee), the trust indeed becomes a very flexible device for generation skipping. ${ }^{124}$ While the spouse is alive, the trustee can invade and pay out the corpus to the grandchild without any transfer tax and without any use of the $\$ 250,000$ grandchild's exemption. By virtue of the last sentence in section 2613(a)(1), this invasion and distribution to the grandchild is not treated as skipping a generation. ${ }^{125}$ After the spouse has died and the child is the income recipient, the grandchild could disclaim any interest in invasions in order to deflect the distribution down to the next generation. Although a transfer tax might be due, the grandchild would be the deemed transferor, probably providing a lower rate bracket than the child has in the unified transfer-tax system. ${ }^{126}$ In a sense, the present generation-skipping provisions and cur-

added only to adjusted taxable gifts and prior generation-skipping transfers. Moreover, the transfer that takes place during the deemed transferor's lifetime (that of the grandchild in our example) will not be cumulated into taxation of later transactions subject to gift or estate taxation. For elaboration of the point that a lower tax burden occurs if the generationskipping tax is imposed on a living deemed transferor rather than on one who has died, see Bloom, supra note 107 , at 63-66.

122 See T. Sharfer, supra note 96, at 263-73.

123 The disclaimer of this benefit seems authorized by I.R.C. section 2518 as that benefit is a single interest in property, separately stated by the transferor. The caveats expressed in the text at notes 77-84 supra, are applicable here, however.

124 The arrangement meets the first test of being a generation-skipping device because both the child and the grandchild are younger-generation beneficiaries. I.R.C. $\S .2611$ (b).

125 " $[\mathrm{A}] \mathrm{n}$ individual who at no time has had anything other than a future interest or future power (or both) in the trust shall not be considered as a younger generation beneficiary." I.R.C. $\$ 2613(a)(1)$. In the textual example, the child's interest is a future interest while the spouse is living. Thus, during this time the arrangement really is not a generationskipping device because the quoted provision causes the scheme to fall outside the definition of I.R.C. section 2611(b) that requires beneficiaries at two or more generations.

123 The assumption is that the grandchild will be at a lower point in the progressive rate structure than the child, his parent. See note 121 supra. 
rent disclaimer treatment may seem to represent similar policy choices. Benefits or control must exist before taxation is imposed. The tax on generation-skipping arrangements is triggered only when the property bypasses a generation at which there is a"beneficiary," that is, one who has an interest in or has certain power to affect the income or corpus. ${ }^{122}$ A person who holds only a future interest or who has but certain minimal elements of control does not rise to the level of a beneficiary. ${ }^{128}$ Similarly, by operation of the theory of relation back, a disclaimant is treated as never having had the rejected interest or control over it. Thus, in the case of a disclaimer, like that of a generation-skipping arrangement, there are no adverse tax consequences unless control is present or benefits are enjoyed.

In the disclaimer situation, however, control and enjoyment of benefits are not present only because the law chooses to say first, that it will observe relation back and second, that the disclaimant's decision to reject is neither control over the property nor enjoyment of it. These principles are highly artificial, and as will be indicated later, ${ }^{129}$ probably unsupportable. Moreover, a conclusion that the operation of the disclaimer mechanism is consistent with exceptions to application of the tax on generation-skipping arrangements is less than compelling since the exceptions are compromise devices that themselves detract from the policy and purpose of the transfer tax on generation-skipping arrangements. ${ }^{130}$ Indeed, the insertion of disclaimer possibilities into generation-skipping trusts merely expands the opportunities for wealthy persons to circumvent this transfer tax. Disclaimer opportunities permit persons other than the original transferor to split benefits between generations while the timing rules offer extended postponement possibilities for taking such action. Thus, disclaimers actually work against the fundamental purpose behind the adoption of the tax on generation-skipping transfers.

The foregoing examples illustrate the uses of disclaimers and the opportunities afforded planners at both the drafting and implementation stages to influence substantially the nature and pattern of the allocation of interests, particularly by expanding the options

${ }^{127}$ See definitions of taxable distribution in I.R.C. section 2613(a) and of taxable termination in I.R.C. section 2613(b), summarized in note 109 supra.

${ }^{123}$ As indicated in note 125 supra, the holder of a future interest is not treated as a beneficiary. The same is true of a person who has only a power to dispose of income or corpus to a beneficiary or class of beneficiaries who are lineal descendants of the original transferor. I.R.C. § $2613(\mathrm{e})$.

12 See Part IV infra.

130 See Bloom, supra note 107, at 35-37 \& $37 \mathrm{nn} .22-24$. 
available to recipients. ${ }^{131}$ They indicate that the new law will encourage not only new and more involved dispositive schemes but also a variety of unusual post-mortem decisions. Heightened complexity, especially when coupled with new incentives for tax minimization, is in itself a high price to pay to implement the traditional policies behind disclaimers. As suggested, this price may become prohibitive once the statute's failure to achieve its goal of uniformity is more widely recognized. These concerns call the desirability of the statute seriously into question and make essential an inquiry into alternatives to the present treatment of disclaimers in the federal tax laws.

\section{In Search of a More Effective Statute}

Given the difficulties section 2518 presents in its current form, it is important to consider how revisions might round off the sharp corners of the statute. Clearly, the current section is preferable to pre-1976 law because it represents progress toward uniformity, and it partially removes some uncertainties concerning the tax consequences of disclaimers, even if it does inject a new level of complexity into the law. Thus, the confusion over the proper application of the new statute, its failure to attain uniformity, and the creation of an atmosphere that encourages complex predeath planning and more extensive post-mortem manipulations all demand a search for modifications Congress might enact to cure these deficiencies.

\section{A. Federal Transfer Mechanism}

As noted earlier, many of the difficulties with the federal statute stem from the requirement in section $2518(\mathrm{~b})(4)$ that the interest pass "without any direction" by the disclaimant and the lack of any mechanism in the statute for transferring the disclaimed property. On the one hand, if the federal law were understood simply to ignore the local property-law characterization of an attempted disclaimer, the disclaimant might be allowed a marital or charitable deduction, for example, without the requisite transfer ever materializing at the state level. On the other hand, even if the federal statute were understood to allow the disclaimant to make a ministerial direction of the interest, the statute still requires some means of identifying the substitute taker, a requirement that throws the statute back to the vagaries of state law. 
One approach to overcoming these difficulties is, of course, for Congress simply to override state law by inserting a transfer rule into section 2518. This transfer mechanism could provide, for example, that if rejection were made within the time and in the manner prescribed, then "the interest shall pass to those who would take if disclaimant had predeceased the creation of the interest." 132 Alternatively, a federal transfer mechanism could be designed to operate only if neither state law nor the instrument creating the interest specifies a substitute disposition. This latter suggestion would both permit diversity according to the desires of the several states and recognize a right in the donor to specify substitute takers, even if it might still encourage drafting in anticipation of disclaimer with the attendant complexity and premium on planning.

The federal transfer mechanism would cause the conflicting state property-law result ${ }^{133}$ to conform to the federal standard.134 It thus avoids the problems created by simply ignoring the state property-law label for federal tax purposes. ${ }^{135}$ This course does raise substantial difficulties, however. Although unlikely under current law, such a federal transfer mechanism might be exposed to constitutional challenge. A decision by Congress to prescribe the taker of disclaimed property if state law does not recognize the need for any shift in ownership would precipitate the question whether Congress has the authority to enact a federal property statute to override state law. Presumably, such federal legislation would be justified as an exercise of power under the commerce clause ${ }^{136}$ or a proper means of exercising the right "to lay and collect taxes." 137 If Congress

${ }_{132}$ Essentially, this proposal adopts a lapse approach for identifying the substitute taker. A hypothetical determination of the disclaimant's heirs, suggested at note 162 infra, would be an alternative or complementary approach. It should of course be noted that simply identifying the substitute taker in the federal statute would, without inserting an actual transfer mechanism, allow implementation of a ministerial-direction approach to the problem. See text and notes at notes $153-160$ infra.

135 The situations referred to here are those in which state law does not recognize a valid disclaimer because state requirements were not met or where state law does not permit disclaimer. See text at notes 12, 35-37 supra.

13 Under the supremacy clause, if there is direct conflict between state and federal law, the federal law would, of course, override the state provision. U.S. ConsT. art. VI, cl. 2. Although Congress might affirmatively articulate its intent to preempt the disclaimer field, it is more likely that Congress would only flesh out the tax consequences of disclaimers, inserting whatever transfer rule would be necessary to provide uniformity. Thus, the states could continue to prescribe property-law requirements and results in disclaimer situations that did not clash with the federal provisions. Cf. Exxon Corp. v. Governor of Md., 98 S.Ct. 2207, 2217 (1978) ("This Court is generally reluctant to infer preemption").

135 See text and notes àt notes $43-47$ supra.

136 U.S. Const. art. I, $\S 8$, cl. 3.

137 Id. art. I, \& 8, cl. 1; art. I, \& 8, cl. 18. 
chooses to regulate an activity under the guise of regulating commerce between the states, the exercise seems to be constitutionally permissible, ${ }^{138}$ although the activity is traditionally within the ambit of local control. ${ }^{139}$ The tenth amendment has been held not to carve out subject matters for the exclusive purview of the states. ${ }^{100}$ Likewise, so long as an intentional exercise of the taxing power raises some revenue and does not transgress the uniformity requirement ${ }^{141}$ or levy a proscribed direct tax without apportionment, ${ }^{142}$ it evidently will not exceed the reach authorized by the Constitution. ${ }^{143}$

Nevertheless, it should be noted that the recent Supreme Court decision in National League of Cities $v$. Usery ${ }^{144}$ has shielded states and their instrumentalities from direct interference in the delivery of governmental services by a federal law that admittedly was otherwise within the scope of the federal power to regulate commerce. The Court was careful to restrict its limitation of federal power to invalidating legislation that threatens the states' sovereign existence and their abilities to deliver governmental services. ${ }^{145}$ Moreover, the decision did not resurrect the notion that the tenth amendment reserves any particular subject matter to the states. ${ }^{146}$ Nevertheless, the Court emphasized "the essential role of the States in our federal system of government."147 Thus, National League of Cities seems to stand for the proposition that our federal system of government presupposes meaningful governmental activities at the

13. "[M]otive and purpose of a regulation of interstate commerce are matters for the legislative judgment upon the exercise of which the Constitution places no restriction and over which the courts are given no control." United States v. Darby, 312 U.S. 100, 115 (1941). Activities that are intrastate in nature may also be subject to federal regulation if Congress believes they have an economic impact or linkage with interstate commerce. Wickard v. Filburn, 317 U.S. 111 (1942); United States v. Wrightwood Dairy Co., 315 U.S. 110 (1942).

150 Regulation of criminal activity (in charging usurious rates of interest for loans and using physical force in collection activities), conduct usually proscribed at state levels, was upheld as a proper exercise of the commerce power in Perez v. United States, 402 U.S. 146 (1971).

160 United States v. Darby, 312 U.S. 100, 123-24 (1941).

14 U.S. Const. art. I, \& 8, cl. 1.

112 Id. § 9, cl. 4.

is See Sonzinsky v. United States, 300 U.S. 506 (1937). The Court recently upheld a federal tax on aircraft use even though applied to a state-owned helicopter used in police work, Massachusetts v. United States, 435 U.S. 444 (1978).

iu 426 U.S. 833 (1976).

${ }^{145}$ Id. at 842,845 .

116 The majority was careful to indicate that the subject matter of the legislation fell within the power to regulate commerce. Only because its application to state and local government interfered with integral governmental matters was it struck down. Id. at 851-52.

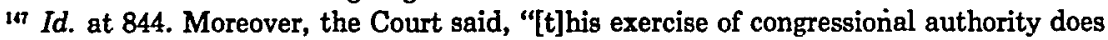
not comport with the federal system of government embodied in the Constitution." Id. at 852. 
state level. ${ }^{148}$ It is problematic whether such activities will be limited to performance of traditional governmental services and functions $^{149}$ or whether this renewed awareness of the role of the states will come to resurrect the idea that states have spheres of regulatory authority Congress cannot abrogate. If the decision presages some movement toward the latter result, Congress might not be able to federalize property law. Certainly, the historical development and implementation of property law, including succession to property, has been a fundamental, exclusive, local concern, ${ }^{150}$ and is thus a logical candidate for any list of inherently local-government activities.

Even if the judiciary does not accept this constitutional objection to federal property law, leaving Congress free to insert a transfer mechanism into the tax provisions on disclaimers, it is possible that Congress itself may feel constrained by such an implicit limitation of a federal system..$^{151}$ In addition, short of the constitutional inquiry lies the basic question of the desirability of a federal system of property law. Even if federal legislation on this subject matter is permissible, the question is whether the country would benefit from a shift, justified by the quest for uniformity, of this legal question to the national arena. If section 2518 were to contain a transfer provision, the caseload of the federal courts likely would be increased to resolve the disputes over its application. Moreover, the very arguments in favor of a federal system-a government close to the people, the ability to experiment at the local level with new legislation, and the freedom to reflect local preferences and cus-

is See L. Tribe, American Constitutional Law $\$ 5$-22 (1978).

14" The Court explicitly referred to "fire prevention, police protection, sanitation, public health, and parks and recreation" as examples of traditional "line and support activities." National League of Cities, 426 U.S. at 851 \& n.16.

150 Though testamentary succession has long been a local matter, the Supreme Court has upheld a federal statute that transferred to the federal government the personal property of any veteran dying in a VA hospital intestate and without heirs. This statute was unsuccessfully challenged by Oregon, which claimed the property of one such veteran pursuant to the state's escheat law. United States v. Oregon, 366 U.S. 643 (1961). For the majority, Justice Black stated, "[t]he fact that this law pertains to the devolution of property does not render it invalid. Although it is true that this is an area normally left to the States, it is not immune under the Tenth Amendment from laws passed by the Federal Government which are, as is the law here, necessary and proper to the exercise of a delegated power." Id. at 649. Justice Douglas, in dissent, took quite the opposite view: "Today's decision does not square with our conception of federalism. There is nothing more deeply imbedded in the Tenth Amendment, as I read history, than the disposition of the estates of deceased people." Id. at 654. The inquiry raised in the text is simply whether National League of Cities suggests the Court is on its way to agreeing with'Justice Douglas.

151 See P. Brest, Processes of Constitutional Decisionmaking 325-26 (1975). 
toms ${ }^{152}$ - suggest rather strongly that restraint and caution are more appropriate than zeal in developing federal property law, even assuming that development is constitutionally permissible.

\section{B. Other Approaches}

Opportunities to improve the operation of the present federal disclaimer statute are available that provide alternatives to creating a federal transfer mechanism. Instead of taking such a radical step, Congress might adopt one of the various proposals for recognizing a disclaimer as valid in those situations in which state law does not shift the property, but the disclaimant transfers the property to the proper next-taker. A number of proposals for disclaimer legislation that antedate section 2518 recommend this kind of a solution. On the one hand, several model ${ }^{153}$ and uniform acts, ${ }^{154}$ proposed for streamlining the states' property laws on this topic, and a proposal for federal reform by the Section of Taxation of the American Bar Association ${ }^{155}$ look to the law of lapse to identify the proper nexttaker, which, insofar as federal tax treatment is concerned, would pave the way for a "ministerial direction" solution. On the other hand, the American Law Institute ${ }^{156}$ and the Treasury Department ${ }^{157}$ have recommended simply that the statute permit the disclaimant to re-transfer the property as he chooses within a reasonable time after the original transfer.

In accordance with the ABA proposal and the tenor of the model and uniform acts, ${ }^{158}$ an amended section 2518 could recognize

152 See generally D. Elazar, The Ends of Federalism: Notes Toward a Theory or Federal Political Arrangements 21-23 (1976).

153 Model Act to Provide for Disclatmer of Succession to Real and Personal Property (Testamentary Instruments); Model Act to Provide for Disclaimer of Succession to Real. AND PERSONAL PROPERTY (Nontestamentary Instruments) [hereinafter cited as Model Acts], in Disclaimer of Testamentary and Nontestamentary Dispositions-Suggestions for Model Acts, 4 Real Prop., Prob. \& Tr. J. 658 (1969) (proposals of the Section of Real Property, Probate and Trust Law of the American Bar Association). For an earlier version of the proposed Act, see Disclaimer of Testamentary and Nontestamentary Dispositions-Suggestions For a Model Act, 3 Real Prop., Prob. \& Tr. J. 131 (1968).

15. UNIFORM Discladmer of Property INTERESTS ACT; UNIForm Disclaimer of Transfrers By WiLl, INTESTACY or APPOINTMENTS ACT; UNIFORM DisCLAIMER OF TRANSFERS UNDER NONTESTAMENTARY INSTRUMENTS ACT. These Acts form the apparent basis for UNIFORM Probate CodE section 2-801 (1975).

iss Tax Section Recommendation No. 1974-2, 27 TAx. LAw. 818 (1974). See also note 52 supra.

1s6 ALI STUdY, supra note 69.

157 House Comm. on Ways and Mrans and Senate Comm. on Finance, 91st Cong., 1st Sess., Tax Reform Studies and Proposals U.S. Treasury Dept. 365-66, 387 (Comm. Print 1969), reprinted in BACKGROUND MATERIALs, supra note 52, at 265-66, 287. [hereinafter cited as Treasury Proposals].

13s Model Acrs, supra note 153, §3. 
refusals that were not treated as disclaimers at the local level by amending the "without direction" language of section 2518(b)(4) and incorporating a lapse-based specification of who the substitute taker should be. A disclaimer would then be effective if the disclaimant, within the stipulated time period, refused the property and assigned or conveyed the interest to the person(s) who would have taken on lapse. The time when lapse would occur, that is the point at which disclaimant is treated as having predeceased, should be the time the disclaimed interest is deemed created. The transfer by the disclaimant would be essentially a ministerial act, would not be discretionary in the sense of choosing the substitute taker, and thus, in accordance with present law, would not constitute the exercise of control justifying imposition of a transfer tax..$^{159}$

There could, of course, be problems in applying the law of lapse in order to determine the rightful recipient. For instance, it may not be clear how to apply an anti-lapse provision, if at all, to an inter vivos gift. ${ }^{180}$ Thus, if the lapse solution is the only external standard available to designate the substitute taker, instances will remain in which an effective disclaimer is impossible. ${ }^{161} \mathrm{~A}$ different mechanism can be provided, however, to handle those transfers made by nontestamentary instruments. Such a mechanism would identify the substitute taker on the hypothesis that the disclaimant died intestate owning the interest on the date the interest was created. ${ }^{162}$ This solution apparently would obviate the most serious of the substitute-taker problems.

Distribution problems might also result, however, from changes (births, deaths, etc.) occurring during the time between the creation of the interest and the disclaimer. Under the relation-back theory, the lapse occurs and the substitute taker is identified under the

iss That is, relation back would be recognized for tax purposes.

16 The concept holds that a testamentary gift fails if the designated taker does not survive the decedent. The donor is dead, so the asset must go to some living person. That taker is identified by the will, the applicable intestacy law or by a so-called anti-lapse statute, which preserves the gift for issue of the intended recipient. See T. Atkinson, Wills $\$ 140$ (1953). If the transfer is inter vivos and the donee is dead, the gift simply fails for lack of a transferee. The transferor then has the property as if no transfer were ever attempted. The concept of lapse has no application. The Model Act covering nontestamentary instruments simply provides that "the interest disclaimed, shall be distributed as if the disclaimant had died before the effective date of the nontestamentary instrument." MODEL ACT To PROvidE for Disclaimer of Succession to Real and Personal Property (Nontestamentary Instruments) § 3. This formulation could leave the transferor as owner of that interest. Thus, a lapse solution may not permit an effective disclaimer in all situations.

101 This problem was àcknowledged in the Tax Section Recommendation No. 1974-2, supra note 155 , at 820 , but no solution was proposed.

112 This approach is utilized in the Maryland disclaimer statute, MD. EsT. \& TRusts Code ANN. §§ 9-204(a)(1), 9-204(b)(1) (Cum. Supp. 1978). 
facts existing at the creation of the interest. The longer the time, the greater the likelihood the substitute will die or others of the substitute class will be born. If the time is simply the relatively short nine-month period for disclaimer, the problem is not too serious. Greater difficulty could arise, however, under the extended time for disclaimer by a minor ${ }^{183}$ if that provision is retained in the statute.

Greater freedom of selection by a disclaimant was proposed in the American Law Institute and in the Treasury Department recommendations. The freedom to select would exist when neither the instrument of transfer nor local law supplies an alternate taker. The ALI recommendation would recognize for federal tax purposes a rejection followed by timely selection of the next recipient even though local law might not characterize the refusal as a disclaimer, indeed even though local law might classify the action as acceptance. ${ }^{164}$ The justification for permitting tax-free selection of the substitute taker is to provide "maximum freedom in post-transfer arrangements" and thereby to reduce the premium placed on advance planning of property dispositions. ${ }^{165}$ The Treasury proposal would permit the disclaimant to designate as taker only someone to whom the original donor could have made a deductible transfer, i.e., a spouse, a charity, or an orphan. ${ }^{106}$

The draftsmen of the Model Acts and of the ABA Section of Taxation proposals gave specific reasons for not embracing freedom of designation by disclaimant. ${ }^{187}$ Such broad authority was simply too much like a power of appointment, the exercise of which necessarily connotes acceptance-with all of its benefits-rather than rejection. The redirection by disclaimant was seen to be at odds with the claim of refusal and rejection.

Such criticisms of a freedom to redirect are undoubtedly on target. The ability to take property in absolute ownership or to transfer it to another who is selected by the recipient is indeed a very broad power. That the decision to accept or re-transfer must be made within a short, nine-month time span does not derogate from the plenary nature of the power. Therefore, if section 2518 were amended to give recognition to a transfer by a disclaimant that shifts the interest to a substitute taker, at the very least the valida-

\footnotetext{
tas I.R.C. § 2518(b)(2)(B).

14 ALI STudy, supra note 69.

is Id. at 39-40.

is TrEasury Proposals, supra note 157, at 365-66, 387.

1074 Real Prop., Prob. \& Tr. J., supra note 145, at 659; Tax Section Recommendation
} No. 1974-2, supra note 153 , at 820 . 
tion should be limited to transfers made to persons identified under some external standard such as the concept of lapse.

A focus on the close relationship between a power of appointment and the disclaimer treatment advocated by the ALI is useful in another sense. Every decision to accept or reject a gift includes the ability to designate oneself as recipient by simply accepting the property. Yet, the power to make oneself the owner of property is the very root of a general power of appointment, ${ }^{168}$ and utilizing a general power to shift ownership to another person is fully subject to transfer taxation. ${ }^{169}$ Such a connection between a general power, seemingly the obverse of a renunciation, and the disclaimer, which presupposes the right to take for oneself, raises more fundamental questions about section 2518 that may preclude mere tinkering with the statute. Indeed, it is essential to consider the argument that the special treatment for disclaimers should be discarded entirely in favor of emphasizing this ability to accept benefits and hence in favor of subjecting disclaimers to estate, gift, and generationskipping taxes.

\section{Disclaimgrs as Transfers}

In essence, section 2518 establishes the rules for giving recognition to the theory of relation back for tax purposes. ${ }^{170}$ The failure to obtain uniformity through a single national rule, the substantial problems confronting attempts to create uniformity, and the complexity and importance the section has brought to pretransfer planning suggest that now is the time to consider abandoning relation back-with all its problems-as a rule of federal tax law. Whether to recognize the effect of the relation back seems fundamentally to be a policy decision; certainly there is nothing in the concept of disclaimer that requires the action to be tax-free. ${ }^{171}$ To be sure, acceptance by the donee can and should continue to be a necessary element for a valid gift. Rejection should be permitted for testamentary transfers-both intestate and testate-as well as for inter vivos gifts. But it does not follow from recognizing the opportunity for disclaimer that the theory of relation back must be observed. As

14 Restatement of Property § 320(1) (1940); I.R.C. \$§ 2041(b)(1), 2514(c).

16 I.R.C. $\S \S 2514(\mathrm{a}), 2514(\mathrm{~b})$. The shift of property rights to another person would not be taxable if the general power was created before October 21, 1942, and the shift resulted from a complete release or certain partial releases of the power. I.R.C. $\$ 2514$ (a).

${ }^{170}$ See text and notes at notes 4 \& 5 supra.

17 Contra, Roehner \& Roehner, Renunciation as a Taxable Gift-An Unconstitutional Federal Tax Decision, 8 TAx. L. Rev. 289, 294 (1953). 
noted earlier, ${ }^{172}$ some jurisdictions do not apply the theory to questions of inheritance taxation and creditors' rights. Therefore, it is appropriate to examine the act of disclaimer and decide whether it is comparable to other actions that are subjected to transfer taxation.

\section{A. Disclaimers and Powers of Appointment}

When a person is offered a gift, he must decide whether to take the property (or interest in property) as an owner or to reject it, letting it pass elsewhere. It cannot be denied that the intended recipient can freely make the property his own. This ability to decide is an element of property control that becomes even greater when the recipient has the ability to make a partial disclaimer. If the recipient has the right to pick and choose between portions of a gift or has the ability to sever the gift and, in effect, create new interests, then the action is more than a simple refusal: it is an assertion of dominion over the property. Of course, in either case, the ability to accept or reject is most certainly not full control; until the recipient makes a decision to become an owner of the interest, there is not the full measure of domination. Nevertheless, full, absolute control is not required to precipitate application of a transfer tax. ${ }^{173}$

Given these principles, the treatment of general powers of appointment offers a most persuasive analogy for justifying taxation of disclaimers. The definition of a general power ${ }^{174}$ looks to the holder's ability to make himself, his estate, or creditors of himself or his estate the owner of the property. The definition does not focus on whether the donee has a broad power to designate other persons, a narrow power to do so, or any such power at all. That a disclaimant cannot designate substitute takers of the rejected property, therefore, does not distinguish a disclaimer from a general power of appointment. Moreover, possession alone of a general power of appointment is sufficient to precipitate taxation notwithstanding failure to take actual benefits. ${ }^{175}$

172 See notes 14 \& 15 supra.

173 See, e.g., I.R.C. $\$ \S 2040$ (estate taxation of interest in tenancy by the entireties even though decedent did not have full control over property under local law); 2041 (estate taxation of property subject to general power of appointment); 2042 (estate taxation of life insurance where decedent may have held only one of the incidents of ownership in the policy); 2514 (taxation of inter vivos exercise of general power of appointment).

174 I.R.C. $\S \S 2041(b)(1), 2514(c)$.

${ }_{175}$ Possession at death of a post-1942 general power causes inclusion in the donee's gross estate of the property subject to the power. I.R.C. $\$ 2041(\mathrm{a})(2)$. Release of such a power will 
On the other hand, the ability of a transferee to claim or reject ownership is significantly different from the control element that inheres in a nontaxable special power of appointment. ${ }^{176} \mathrm{~A}$ special power that is accepted and held by the donee, by definition, does not bestow upon the donee the right to take the property. Thus, transfer treatment of disclaimers is not inconsistent with the existing design for taxing powers of appointment, which taxes general powers but exempts special powers. Indeed, the very distinction now employed for powers of appointment dictates a change in the treatment of disclaimers; the Code clearly views the power to take property, as distinguished from the power to direct it, as a critical factor justifying transfer taxation of an interest in property.

These concerns for the degree of control held by the donee also clearly underlie the tax law's treatment of relation back in the context of powers of appointment. Property law generally does apply relation back to power-of-appointment situations. Thus, when the donee of a power exercises it to designate the appointee, title to the appointive property passes directly from the donor of the power to the appointee. ${ }^{177}$ Nevertheless, the donee's action remains important. The appointee's title depends upon the combination of both the donee's and donor's actions. ${ }^{178}$ Consequently, although the relation-back principle generally ignores the donee's role, the tax law does not always do so. If the donee possesses the ability to make the property his own, the choice of another as recipient becomes more significant, and the federal tax law views the donee as an owner-transferor. ${ }^{179}$ The tax-law policy choice turns on the amount of discretion held by the donee. That is, to use the fictional language, the concept of relation back is ignored for tax purposes in

cause inclusion in the gross estate if the release effected a shift in property interests essentially equivalent to a transaction that is subjected to estate taxation under I.R.C. sections 2035 through 2038. Id. Possession at death of a general power created before October 21, 1942 is not taxable if the power is not exercised. I.R.C. \$ 2041(a)(1). An inter-vivos exercise or release of a general power created after October 21, 1942 is a transfer subjected to gift taxation. I.R.C. $\$ 2514$ (b). A complete release and certain partial releases, however, are not taxable if the general power was created before October 21, 1942. I.R.C. § 2514(a).

${ }^{176}$ A special power of appointment as used here refers to any power other than one coming within the tax definition of a general power of appointment under I.R.C. sections 2041(b) and 2514(c). Thus, here a special power encompasses both the property-law special power (one that can be exercised by the donee in favor of members of a group that is not unreasonably large, and does not include the donee) and a hybrid power (the objects of the power being broader than permitted under the property-law special power but still not including the donee of the power). These distinctions are fully examined in Restatement of Property $\$ \S 320,323$, comment h (1940).

175 American Law of Property $\$ 23.3$ (A.J. Casner ed. 1952).

173 See id.; L. Simes \& A. SMTTH, supra note 58, § 913, at 377.

17 See notes 174-175 supra. 
instances in which the donee could have made the property his own.

Again, a similar analysis can be made of the disclaimant's role when he rejects a gift. It is not necessary to contend that the disclaimant owned a property interest or that the ultimate taker took title from the disclaimant. For property-law purposes, the substitute taker may be viewed as acquiring his interest from the original transferor; the fiction of relation back can still be employed. Any clear analysis must admit, however, that the substitute taker acquired title only because two actions combined to place title in him: the action of the transferor in conveying to the disclaimant and the disclaimant's act of rejection. As a matter of causation, both acts were necessary. Moreover, both were voluntary. ${ }^{180}$ That the disclaimant's right to reject is said not to be a property right, and the rejection is not called a transfer or conveyance cannot explain away these two characteristics.

A transfer tax is an excise imposed upon a transfer or shift in ownership rights. ${ }^{181}$ Since the disclaimant's act is a necessary step in the ultimate taker's accession to ownership rights, here, as in the case of a general power, it is necessary for tax purposes to look through the relation-back theory that is otherwise applied to the disclaimant's action. In short, since the disclaimant has the discretion to accept property as his own, there undoubtedly exists a voluntary, discretionary act that shifts ownership. Thus, even if, as in the power-of-appointment situation, the tax consequences of the disclaimant's act seem purely a policy decision, consistency demands that the disclaimer be subjected to transfer taxation.

An argument in reply to this line of reasoning is that a power of appointment presupposes a prior acceptance of the power whereas the disclaimer decision comes before that previous acceptance step. Though correct as a matter of theory, in practical terms this distinction uses labels to hide the element of control that exists at that earlier stage. If the realities of the situation are assessed and focus is placed on elements of control, benefit, and enjoyment rather than on labels from the law of property, the rationale for transfer taxation becomes highly compelling.

\section{B. Scope of a Transfer-Tax Rule}

A similar attention to practical details suggests that the treatment of disclaimers as transfers should not subject all disclaimers to tax treatment. If the decision were to accept or reject a special 
power of appointment, for example, a rejection would not precipitate inclusion of any amount in the disclaimant's transfer-tax base: the disclaimant was always insulated from any actual ownership of the property. Had acceptance been made, followed by exercise or release, the later transaction would not be subject to taxation. ${ }^{182}$ Rejection at the outset should not produce a contrary result.

Other literal applications of a rule treating disclaimers as taxable transfers may present greater difficulties, however, especially in the allocation of deductions. Assume $H$ dies intestate survived by his wife, $W$, and two adult children, $A$ and $B$. If both children disclaim, W's interest may be enlarged from one-third to all of $H$ 's estate. ${ }^{183}$ If the disclaimers are treated as transfers by $A$ and $B$, it would seem to follow that the marital deduction allowable in $H$ 's estate remains one-third of the estate and is not enlarged. ${ }^{184}$ Nor would a deduction be allowed to $A$ or $B$, since specific requirements for the marital deduction are not satisfied. ${ }^{185}$ If a charity is the substitute taker following a disclamer, it would also appear that because relation back is not applied, no charitable deduction is available to the original transferor. ${ }^{186}$ The disclaimant, however, should be able to claim the charitable deduction, even though the transfer to charity resulted from a decision not to take the property himself rather than any charitable motive.

Since not all disclaimers will shift a fee interest or an undivided portion of the whole, departures from the literal rule seem sensible. Consider two examples. First, a transferor may intend to create a charitable remainder unitrust, ${ }^{187}$ complying fully with the statute except for the insertion of an impermissible, discretionary power of invasion in the trustee to benefit the noncharitable income benefici-

isz Special power here means a power other than a general power of appointment, supra note 176. Hence, it is not subject to estate or gift tax. Possession of certain special powers (those failing to come within the exception in I.R.C. section 2613(e)) may subject a trust or trust equivalent to the provisions of the tax on generation-skipping transfers. Thus, in a sense, rejection of a special power may negate the possibility of a later taxable transfer. Nevertheless, it seems simpler to treat disclaimers of all special powers as nontransfers.

${ }_{180}$ The example assumes that $A$ and $B$ have no children so that the lapse approach to disclaimer would give the entire estate to the surviving spouse as the only intestate taker. Obviously, this result would not occur if the applicable local law identified takers other than $W$ as the substitute recipients.

${ }^{13}$ Without relation back, the requirement of I.R.C. section 2056(a) that the property pass from the decedent to the surviving spouse is not satisfied.

185 The transferor (disclaimant) has not left property to his spouse. I.R.C. $\S \S 2056(a)$, 2523(a)(1).

${ }^{186}$ At stake could be an income-tax charitable deduction under I.R.C. section 170; an estate tax deduction, I.R.C. section 2055; or a gift tax deduction, I.R.C. section 2522.

${ }^{187}$ I.R.C. $\$ 664(d)(2)$. 
ary. ${ }^{188}$ Second, a wife may have created a trust for her surviving husband that meets the conditions for the marital deduction except that the power of appointment given to the husband is exercisable only with the consent of a daughter. ${ }^{189}$ The issue in the first example is whether the unitrust beneficiary can disclaim all benefits under the power, so that the transferor may obtain a charitable deduction; in the second, the question is whether the daughter can disclaim the right to exercise, so that the wife's estate obtains a marital deduction. In neither case would the disclaimant be effecting a taxable transfer, ${ }^{190}$ so neither should be eligible for a deduction. On the other hand, both original transferors intended and attempted to qualify for a deduction. ${ }^{101}$ Perhaps equally important, the fragmentary interest disclaimed was not absolute ownership nor an undivided interest.

The situation in each case is one in which the transferor has acted upon the motivation supplied by the Internal Revenue Code and the disclaimant has rejected an interest that normally would not be the sole subject matter of a deductible transfer. In such a case, the relation-back fiction might be applied as a policy choice to affect the tax results. That is to say, if a disclaimant rejects a fragmentary interest (neither a fee nor undivided portion thereof) that joins with a direct transfer from the donor to qualify for a deduction, the deduction might be allowed to the original donor. Where the disclaimant rejects the whole or an undivided portion, however, and the result is passage in a form that may generate a deduction, no similar rationale counsels the granting of the deduction to anyone but the disclaimant.

188 This term is proscribed by I.R.C. section $664(\mathrm{~d})(2)(B)$.

18 I.R.C. section 2056(b)(5) articulates the conditions to be met before a trust benefiting a surviving spouse but violating the terminable interest rule of I.R.C. section 2056(b)(1) will qualify for the marital deduction. One requirement is that the spouse be given a general power of appointment "with no power in any other person to appoint." I.R.C. § 2056(b)(5). See also Treas. Reg. \& 20.2056(b)-5(g)(3) (1958).

im If the beneficiary of the unitrust accepted status as permissible beneficiary of the discretionary power of invasion, it is unlikely the interest could be validly assigned to another person. Even if it could be, the value would be near zero since benefits, if any, are within the trustee's discretion. If the beneficiary died possessing this right, it undoubtedly then ceases and thus is not includible for estate tax purposes. I.R.C. $\S 2033$. Whether this person can accept the right to receive the unitrust periodic payment but effectively disclaim the right to discretionary invasions of corpus depends on whether and to what extent partial disclaimers are recognized. See discussion at notes 76-78 supra.

The daughter who is offered the ability to be coholder of the general power of appointment would not be treated as the donee of a general power if she should consent to an exercise of or die possessing this power. I.R.C. $\$ \S 2041$ (b)(1)(C)(ii), 2514(c)(3)(B).

in' If one of the reasons for the existence of the marital and charitable deductions is to encourage gifts to spouses and charities, it seems the deduction should be allowable, if at all, to the person who has been motivated to leave his or her property in that fashion. 


\section{Other Considerations}

1. Tax Policy. Classifying disclaimers as transactions generally subject to transfer taxation would recognize the substantial control and enjoyment implicit in the decision to accept or reject property, and thereby remove an inconsistency in present law. More importantly, such a rule would facilitate attainment of the goals and policies of estate and gift taxation. A primary raison d'etre for transfer taxation is to limit the transfer of wealth and, in so doing, to reduce economic inequality. ${ }^{192}$ It is the egalitarian impulse, not revenue production, that fuels its momentum and should therefore shape its design.

As disclaimers now operate, however, they offer considerable opportunity for tax minimization and avoidance. The existence of disclaimer possibilities permits delay in allocating shares among family members; this feature in turn allows passage of property to other family members when the named recipient has adequate wealth from other sources. These adjustments in property distribution can be used most often by persons who have sufficient resources to permit the luxury of refusing property. Persons with modest means cannot afford even to entertain the idea. They accept, possess, and use their property, and they suffer the consequences of transfer taxation when the residue passes to the next family member. Disclaimers, then, present opportunities to keep wealth intact. In this respect, they work contrary to the basic purpose of wealth taxation. This policy-defeating feature and the resultant inequity among taxpayers can be corrected by removing the tax-free option offered by disclaimers.

A similar conclusion results from the concept of a comprehensive tax base, which is used often in income tax discussion as a guide to the proper definition of gross income. ${ }^{193}$ If that idea were applied to transfer taxation, disclaimer situations are logical nominees for inclusion in the comprehensive transfer-tax base. A comprehensive

192 Another reason, of course, is to raise revenue. See Jatscher, The Arms of Death Taxation, in Death, TaXes and Family Property 40, 51 (E. Halbach ed. 1977) for an evaluation of reasons advanced for imposition of estate taxes and the conclusion that the redistributive purpose is its most legitimate objective. A similar view regarding the rationale for transfer taxes is expressed in U.S. Treasury Dep'T, Blueprints For Basic TAX REForm 139 (1977); H. Simons, Personal Income Taxation 126, 130-31 (1938). Cf. Eisenstein, The Rise and Decline of the Estate Tax, 11 TAX. L. REv, 223 (1956), reprinted in READINGS IN DEÁtH AND GIFT TAX REFORM at 3 (G. Goldstein ed. 1971) (indicating revenue production was the original goal of estate taxation).

133 See, e.g., 3 Report of the Royal Commission on Taxation 6-7, 22-25 (1966) (Canada) [hereinafter cited as 3 RePorT]; H. Simons, supra note 192, at 41-58, 205-13; U.S. TrEASURY DEP'T, supra note 192, at 3-9, 53-112. 
income-tax base focuses on total receipts as the proper measure of tax-paying capacity. Exclusions and deductions are made only for well-articulated, significant reasons. ${ }^{194}$ In transfer taxation, the total amount of the wealth that is shifted to new owners should constitute the comprehensive base. Disclaimers would be included in and remain part of this base because the disclaimer is a volitional and necessary component of the shift of wealth to a new owner, and because no significant policy mandates exclusion.

2. Policy Objections. There are, of course, arguments other than those already noted against this change in the tax approach to disclaimers. It is worth considering a fair selection of these objections here. One significant argument is that taxation of a refusal to accept property is unconstitutional. ${ }^{195}$ But no valid constitutional argument should exist on the ground that the transferor did not "own" the property levied upon. ${ }^{196}$ Nor should it be fatal that the

19 The actual measure of the comprehensive income-tax base is all consumption plus the net increase in wealth over the tax period. This figure is computed by including all receipts and deducting expenditures other than those that confer personal benefit. Departures from this ideal base are made only for compelling administrative, economic, or policy reasons. 3 REPORT, supra note 193, at 37-58; H. SimoNs, supra note 192, at 205-14; U.S. TREASURY DeP'T, supra note 192, at 2. Although advocates of a comprehensive income-tax base would subject gratuitous receipts (gifts and inheritances) to income taxation, they do not necessarily advocate total abolition of transfer taxation. Compare H. Simons, supra note 192, at 144-45 and S. SurRey, Pathways to TAx Reform 286 n.6 (1973) ("Probably our society would not be content to leave the taxation of inherited wealth solely to the application of the income tax.") with 3 RgPORT, supra note 193, at 477.

193 That proposition was raised in response to the court's holding in Hardenbergh v. Commissioner, 198 F.2d 63 (8th Cir. 1952), cert. denied, 344 U.S. 836 (1952), that the renunciation of an intestate share should be taxed as a gift. Since the chief concern in that context was denial of equal protection or due process, or both-because testate shares admittedly could be renounced without adverse tax consequences, Hardenbergh, 198 F.2d at 66; see Brown v. Routzahn, 63 F.2d 914 (6th Cir. 1933)-this argument seemingly loses its force if both types of transfers receive the same treatment albeit not the one favored by taxpayers.

The specific constitutional objection is unclear, however. It has been questioned whether it is not clear that " $\mathrm{a}$ tax on the renunciation by an heir is so arbitrary or capricious as to violate the Constitution." Roehner \& Roehner, supra note 171, at 291 . They also state that "the right to reject an inheritance is an inalienable right which cannot be taxed by the Government consistently with the Fifth Amendment." Id. at 294. This latter assertion seems not to square with the generally perceived right of government to tax property or its transfer. See the authorities cited note 199 infra.

13 Property covered by a general power of appointment is subjected to transfer taxation even though the holder of the power did not "own" the property. See note 175 supra. Similarly, certain property in which the decedent has no interest at death, over which he has no control, and from which he receives no benefit is subjected to tax if it was transferred within three years of death. I.R.C. $\$ 2035$ (a). The predecessor to the present section was found to satisfy constitutional requirements in Milliken v. United States, 283 U.S. 15 (1931). In considering the validity of the present version, see Heiner v. Donnan, 285 U.S. 312 (1932). Finally, property transferred subject to a retained right to revoke is placed in the estate tax base by I.R.C. section 2038(a), although the decedent technically did not own the property at death. Such taxation also passes constitutional muster. Porter v. Commissioner, 288 U.S. 436 (1933). 
interest was not actually transferred by the disclaimant. ${ }^{197}$ Moreover, since section 2518 itself taxes rejections that are valid under local law when federal requirements are not satisfied, Congress apparently saw no constitutional barrier to taxation of valid refusals to accept property. Also noteworthy is the existence of state inheritance-tax laws that treat a disclaimant as a recipient of property for tax purposes. ${ }^{198}$ The inherent power of the legislature to regulate succession to property justifies and permits limitations in the form of taxation on the rights involved here. ${ }^{199}$

Another objection might be that the law would be "absurd" in forcing a person to take an unwanted gift. This argument gains support from the long history of recognizing the ability to disclaim. But the present proposal does not threaten the ability to disclaim. Renunciations that are valid under state law would still be available to deflect transfers; a gift truly viewed as burdensome could still be rejected. To be sure the relation-back theory would not be recognized for tax purposes and the tax consequences would thus become an element to assess in making the decision to accept or to reject. But if a gift were genuinely burdensome in the sense that it was subject to a large lien or other significant monetary obligation, that condition would probably so reduce the net value of the gift that, even if a disclaimer were treated as a taxable transaction, the small value of the transferred interest would precipitate little or no tax effect.

Double taxation or, more accurately, the prospect of two successive taxes within a short period of time is another potential objection. The original donor may be subject to gift or estate taxation. If a disclaimer is treated as a transfer subject to tax law, a second exaction is made shortly after the original one. Yet, not only can this successive taxation occur in nondisclaimer contexts when successive transfers take place, there is no discernible policy suggesting that

197 Possession alone without exercise of a general power is a sufficient nexus for powers created after October 21, 1942. See authorities note 175 supra. An insurance policy insuring the decedent is includible in his gross estate under I.R.C. section 2042(2) if he held the right to borrow against the policy even if another person held the right to change the beneficiary and actually exercised that right to transfer the proceeds at the decedent's death. See Treas. Reg. $\$ 20.2042-1$ (c) (1974).

198 See Conn. Gen. Stat. Ann. $\S 45-312$ (West Cum. Supp. 1978); 1945 Cal. Stats. c. 1014, $\S 2$ (current version at CAL. REv. \& TAX Code $\$ 13409$ (West Cum. Supp. 1978)); 1953 Ind. Acts c. 112, $\$ 604$ (current version at IND. CoDE ANN. $\$ 29-1-6-4$ (Burns Cum. Supp. 1978)). The constitutionality of the California statute was approved in Estate of Nash, 256 Cal. App. 2d 560, 64 Cal. Rptr. 298 (1967).

193 Irving Trust Co. v. Day, 314 U.S. 556 (1942) (state inheritance tax); New York Trust Co. v. Eisner, 256 U.S. 345 (1921) (federal estate tax); Estate of Nash, 256 Cal. App. 2d 560, 64 Cal. Rptr. 298 (1967). But see Nunnemacher v. State, 129 Wis. 190, 108 N.W. 627 (1906). 
there is anything inherently wrong with two taxes in quick succession. Although the credit for tax on prior transfers ${ }^{200}$ mitigates the blow of successive estate taxation caused by two deaths within up to a ten-year period, the policy reflected in that provision responds to the burden of taxes imposed on involuntary transfers. The policy does not and should not apply when the second transfer is voluntary, as in a disclaimer. ${ }^{201}$

Collection of the tax may be perceived as troublesome, thus raising an argument of administrative difficulty. The putative transferor for federal tax purposes is the disclaimant who, by virtue of local property law, never was the owner of the transferred assets. Without ownership of that property, he may lack ability to pay, and imposition of liability upon him indeed may appear harsh. Although generally the disclaimant should be treated the same as a donor would be treated under the gift tax, ${ }^{202}$ the new tax on generationskipping transfers suggests a workable, alternative collection theory and procedure..$^{203} \mathrm{~A}$ disclaimant should be required to file the gifttax return and supply any other information necessary either to compute the tax or to use the unified credit at the proper rate brackets. The disclaimant should be permitted, however, to elect to have the tax paid from the disclaimed property. ${ }^{204}$ This election would become automatic in the event the disclaimant fails to make a return, ${ }^{205}$ and the substituted taker then should be empowered to request and receive from the Secretary enough information about the disclaimant's position in the unified transfer-tax system to permit the filing of a return. ${ }^{208}$ The tax would be a lien on the disclaimed property and the substitute taker would be liable for tax

200 I.R.C. $\$ 2013$.

201 An instructive omission is the lack of any such credit when transfers in quick succession are subject to gift tax.

202 Thus, the unified credit, I.R.C. $\$ \S 2505,2010$, should be available to offset tax on the disclaimant and the value of the disclaimed property should be included in the disclaimant's cumulative taxable gifts under section 2503.

See I.R.C. $\$ \S 2603,2621$ (c).

201 The statute imposing tax on generation-skipping transfers, I.R.C. $\S 2601$, does not state where the tax comes from. I.R.C. section 2603 imposes personal liability on the trustee when the tax is generated by a taxable termination (defined in I.R.C. $\$ 2613(\mathrm{~b})$ ) and on the distributee in case of a distribution. The legislative history, however, states: "Generally, it is anticipated that the tax will be paid out of the proceeds of the trust property." House REPORT, supra note 29 , at 57. If this approach were adopted for disclaimer purposes, the gift tax payable from the property would reduce the net value of the transfer. See Rev. Rul. 75-72, 1975-1 C.B. 310, for computation of the tax under these circumstances.

205 The provision for automatic shifting of the tax burden will prevent the disclaimant from being labelled a tax deliquent for merely refusing to accept unwanted property.

200 See I.R.C. \$ 2603(a)(2). 
up to the fair market value of the property when received. ${ }^{207}$

The ramifications the proposed rule might have on statutory succession rights may present yet another objection to adopting transfer treatment for disclaimers. Commentators in the past have expressed concern that a surviving spouse or a pretermitted child might be making a taxable gift on failure to claim his or her statutory share. ${ }^{208}$ If this application of the logic that rejections should be equated with transfers is too troubling, a short, quick response is to exempt statutorily created rights. Such a response merely avoids analysis of the objection, however, since a close examination indicates that there is really no great problem with extending the logic of the proposed rule to these cases. In the case of the surviving spouse, a dower or substitute statutory right is really an election to take either under the decedent's will or to take the statutory share. ${ }^{209}$ When the gift from decedent exceeds the statutory share, there may be no right to elect. ${ }^{210}$ If so, no possible question of a refusal arises.

If, on the other hand, a choice still exists, although the gift is larger than the elective share, there clearly is no excess going to other persons. In a sense, the spouse has exchanged the statutory right for more than full and adequate consideration, and has not undertaken a gratuitous transfer to which tax should apply. Although relinquishment of dower, curtesy, or other marital rights ordinarily is not treated as consideration in money or money's worth, ${ }^{211}$ the general reason for this rule-to tax as a gift a transferor's shift of property to the natural objects of his bounty ${ }^{212}$-actually suggests that relinquishment of statutory rights should be treated as consideration, given the realities of this exchange. If the spouse's election is to take the larger of the alternatives, the spouse's estate is not in any sense being depleted; there is no net shift of property to any of the spouse's natural objects. On the other hand, if the spouse's statutory right is greater in value than the transfer the spouse accepts under the will (or if the spouse

${ }^{207}$ See I.R.C. $\$ \S 2603(\mathrm{a})(3), 2603(\mathrm{~b})$.

${ }_{208}$ See Black, The Effect of Renunciations and Compromises on Death and Gift Taxes, 3 Vand. L. Rev. 241, 268-69 (1950); Bowe, Gifts and Taxes, 18 U. Cin. L. Rev. 237 (1949); Note, Will Renunciations of a Bequest or Failure to Claim a Statutory Share Constitute a Taxable Gift?, 2 VAND. L. REv. 87 (1949). Under current law, the spouse's unexercised right of election is not subject to transfer taxation. See Rev. Rul. 74-492, 1974-2 C.B. 298.

2091 AMERICAN LAW OF Property $§ \S 5.41,5.42$ (A. J. Casner ed. 1952); T. AtKINSON, Whls $\S 33$ (1953).

210 E.g., N.C. GEN. STAT. $§ 30-1$ (1976).

21t I.R.C. $\$ 2043(\mathrm{~b})$. This is an estate tax provision, but the same rule applies with respect to gift tax, Merrill v. Fahs, 324 U.S. 308 (1945).

212 Commissioner v. Wemyss, 324 U.S. 303 (1945). 
elects a statutory right that is less than the rejected gift under the will), the use of a consideration principle helps to reveal what the excess really is-a gratuitous transfer by the spouse to the substitute takers.

Analysis of the pretermitted-child situation is similar except that an election is an all-or-nothing decision. The statutory right generally is created because the testator's failure to give anything to the child implies he or she was omitted inadvertently. ${ }^{213}$ Thus, a decision not to claim the pretermitted share is an election to take nothing. In reality, though, the child has unfettered command over a certain amount of property, the same element of control any recipient has when called upon to decide whether to accept. The decision to reject or ignore a gift (private or statutory) results from a weighing of advantages and disadvantages that shows the scales tipped in favor of rejection. That is, this person, in his unique situation, believes that more benefits flow from rejection than from acceptance. Consequently, this analysis suggests that a failure to claim the statutory share should be treated as a transfer.

The share that a pretermitted child refuses is in most cases likely to go to the surviving parent or to siblings. ${ }^{214}$ The elective share a surviving spouse ignores is likely to flow to children or others younger than the spouse. ${ }^{215}$ This difference in identity of the substitute taker could afford a rationale for excepting from transfer treatment the rejection of pretermitted shares, but not the shares of surviving spouses. The basis for the exception would be that a transfer to a parent or to siblings is a less serious exception than a gratuitous shifting of interests to a younger generation. ${ }^{216}$ Such an exception might also be bolstered by administrative considerations. Since pretermitted children often are minors, the decision to claim

213 T. Atkinson, Wills § 36 (1953); see, e.g, Uniform Probate Code § 2-302.

211 This statement is based on the empirical finding in a recent study of the probate process that when a testator deviates from the pattern of disposition provided by intestacy laws, it is common to leave all property to his or her spouse. M. Sussman, J. CatzS \& D. Smith, The Family and INHERTtance 89 (1970). In addition, since many pretermitted heir statutes protect only children born or adopted after execution of the will, the testator may well have provided for older children but not the omitted child.

${ }^{215}$ This statement assumes the decedent left lineal descendants or collateral kin who would take under an alternative provision of the will. This assumption may be fair in light of the finding that only a small percentage of testate decedents leave property to unrelated persons. M. Sussman, J. Catrs \& D. Smith, supra note 214, at 108-13.

216 In effect, the distinction would embrace the idea that a transfer tax should be imposed once a generation as the property passes to a younger generation. This concept was used in support of the argument for the tax on generation-skipping transfers. HousE REPORT, supra note 40 , at $46-47$. No such concept is found in the gift tax, and its validity is probably restricted to transfer at death. 
the statutory share may involve a court proceeding, which the child arguably should not have to invoke on pain of transfer treatment for failure to do so.

3. Other Issues. There is little doubt that transfer treatment of disclaimers would shift the burden for proper planning back to the owner of property. It is submitted that the original owner of the property is the proper party on whom that burden should rest. The law of gratuitous transfers recognizes the rights and opportunities in an owner to direct the disposition of his or her property. On the other hand, neither property nor tax law has developed a sophisticated concept of dispositive realignment by the intended donee. Section 2518 aids and abets development of an expanded concept of allowing a donee who is still at the stage of being a nonowner to partially modify dispositions. As suggested earlier, ${ }^{217}$ such a rule really does not eliminate the burden of planning, but rather mandates a different type of planning by the owner, carries new penalties for those donees whose donors fail to plan in advance, and places a new post-transfer planning burden on the recipient. Transfer treatment for disclaimers would eliminate these new premiums on planning and their concomitant penalties for recipients whose donors fail to plan, or who themselves fail to do so.

The simplicity and fairness of treating disclaimers as transfers overshadows the several objections to this fundamental change. The change is simple because it does not require national uniformity. State laws can vary, but a disclaimer would be a transfer for federal tax purposes, however it might be defined in property-law terms. Fairness results because all disclaimants would be treated as transferors. No longer would some receive favorable and others unfavorable tax treatment. In addition, this change would eliminate the present law's incentives to plan and draft to facilitate disclaimer and to create complex dispositions. At the same time, although the tax burden is increased, the effect will be felt primarily by those persons who have sufficient wealth to take advantage of disclaimer opportunities. Finally, since the change will definitely restrict and limit the ability to shift property without tax consequences, it will further the goals and objectives of estate and gift taxation.

\section{CONCLUSION}

Although the motivation behind the 1976 federal disclaimer rule was salutary, the uniformity sought has remained elusive. Sig- 
nificant variations persist so that persons similarly situated remain subject to substantially different tax consequences. Moreover, the new statute contains numerous uncertainties in interpretation and application that detract from its ability to fulfill its mission. Equally serious are the new complexities injected into the estateplanning process, the opportunities presented for planners to avoid the thrust and the policies of transfer taxation, and the greater need presented for sophisticated advice.

Modifications are available that would cure some of these defects. Given the constitutional and policy objections, a federal transfer rule that would supersede inconsistent and incomplete state transfer rules is probably not a viable alternative. But a decision to permit the disclaimant to transfer title to a substitute taker when state law fails to designate one seems a realistic, if limited, suggestion. Such permission must be circumscribed, however, so that the substitute is identified by an external source, such as the law of lapse, rather than by the disclaimant.

Tampering with the present section 2518 is not the ideal solution to the imperfections of current law, however. A more direct and more beneficial resolution can be attained by dropping the notion that disclaimers must be nontaxable events and by pursuing the idea that disclaimers generally are equivalent to taxable transfers and should be subject to taxation. This reversal of approach would result in simpler and fairer treatment-eliminating the nonuniformity, complexity, uncertainty, and undue emphasis on planning that plague the present law-as well as a better alignment with the goals of estate and gift taxation. 